\title{
Vocational training choice from a regional perspective
}

\author{
Katja Schuster ${ }^{*}$ and Anne Margarian
}

\author{
*Correspondence: \\ katja.schuster@thuenen.de \\ Thünen Institute of Rural \\ Studies, Bundesallee 64, \\ 38116 Braunschweig, \\ Germany
}

\begin{abstract}
Motivated by discussions of skill mismatches on local German vocational educational and training (VET) markets, this paper analyses how occupational segments of VET entry of individuals with lower and intermediate secondary school degree relate to local labor market characteristics. The econometric analysis applies data from a survey conducted with 9th graders within the German National Educational Panel Study (NEPS). Considering opportunity structures and the local competition for training positions, we find that the match between occupations'skill demands and individuals' abilities tends to be specifically close in diverse and competitive urban labor markets. In non-competitive peripheral labor markets, in contrast, graduates with lower school certificates seem to have a higher likelihood of entering VET in segments that are specifically attractive for graduates with upper secondary school degree. The results on the allocation of abilities and the weight of preferences under different labor market conditions have different welfare implications from an individual, regional and general economic perspective.
\end{abstract}

Keywords: Occupational choice, Vocational training, Local labor market, Local occupational structure, school-to-work transition, Multinomial logit model

\section{Introduction}

Local vocational education and training (VET) within firms and schools is crucial to generate the specific skills required by employers and industries in Germany (Baethge and Wolter 2015). In peripheral regions, residents' VET choices are specifically relevant for the maintenance and enhancement of economically valuable skills due to low in-migration. As the requirements of firms and industries vary across space, local training and career opportunities vary regionally as well. These opportunity structures can be expected to affect the occupational segment of VET entry due to residents' restricted mobility and information. That space matters has been confirmed by the observation that the distance to educational institutions affects educational choices (Frenette 2006; Gibbons and Vignoles 2012; Sá et al. 2006). Despite the expectable adaptation of training opportunities to industry demands and of VET entry segments to training opportunities, mismatches have been observed on the occupational, regional and qualification level on Germany's VET market (e.g.,Autorengruppe Bildungsberichterstattung 2018; Bundesagentur

(c) The Author(s) 2021. This article is licensed under a Creative Commons Attribution 4.0 International License, which permits use, sharing, adaptation, distribution and reproduction in any medium or format, as long as you give appropriate credit to the original author(s) and the source, provide a link to the Creative Commons licence, and indicate if changes were made. The images or other third party material in this article are included in the article's Creative Commons licence, unless indicated otherwise in a credit line to the material. If material is not included in the article's Creative Commons licence and your intended use is not permitted by statutory regulation or exceeds the permitted use, you will need to obtain permission directly from the copyright holder. To view a copy of this licence, visit http://creativeco mmons.org/licenses/by/4.0/. 
für Arbeit 2017; Dummert et al. 2019). Mismatches between preferences and occupational attributes, or incomplete exploitation of abilities, cause underutilization of the production factor labor and welfare losses (Ghignoni and Verashchagina 2014; Levels et al. 2014; Nordin et al. 2010; Somers et al. 2019).

Against this background, this paper asks in how far certain regional labor market characteristics affect the likelihood of entering a particular occupational segment of VET given a graduate's observable preferences and abilities. More specifically, we ask how local labor market characteristics affect the match between the characteristics and requirements of an occupational segment on the one hand, and the preferences and abilities of graduates on the other hand. Most existing studies analyze the vertical differentiation in educational decisions and focus on schooling and academic training choices (e.g., Mocetti 2012; Nguyen and Taylor 2003). Albert (2000), for example, shows that respective employment expectations affect the decisions for different education levels. More specifically, school graduates in regions with good opportunity structures have been found to be more inclined towards further participation in general education rather than in the VET system compared to graduates in less advantaged regions (Glauser and Becker 2016).

Our exploratory analysis addresses the research gap on the horizontal choice of an occupational segment in VET entry at different locations. It concentrates on the short-term relationship between given preferences and abilities of mobilityrestricted graduates from lower and intermediate secondary schools (LSS and ISS), local labor market characteristics at their initial location, and the occupational segments of their VET entry. The analysis builds on data from the National Educational Panel Study (NEPS) complemented by regional context variables. A multinomial logit (MNL) model is applied to analyze the entry of graduates into eight occupational segments, and interaction terms capture the moderating effect of local labor markets on the relation between graduates' abilities and preferences and segments of VET entry.

Despite its (self-) restrictions, the analysis provides important first insights into an under-researched field. Specifically, we find that the match between skill demands and individual abilities tends to be particularly close in diverse and competitive urban labor markets. Given the weaker competition from higher-qualified graduates and despite the limited opportunity structure of rural labor markets, graduates with LSS degrees appear to have better chances of realizing certain career preferences in thin, peripheral labor markets than in urban regions.

The Section "The (German) VET market" of this paper begins with a description of the German VET markets taking into account the aspects that are important for the analysis. Section "Literature Review and Theoretical Framework: The regional perspective" provides a literature review on educational choices and VET entry from a regional perspective before it develops a conceptual framework and derives hypotheses in a synthesis of Sects. "The (German) VET market "and "Literature Review and Theoretical Framework: The regional perspective". Sect. "Method and data" describes the empirical strategy and explores the data. Sect. "Result" presents and discusses estimation results. Sect. "Conclusion" concludes. 


\section{The (German) VET market}

The German education system is characterized by a distinction between academic general education on the one hand, and practical vocational training on the other hand (Ludwig-Mayerhofer et al. 2011). Also characteristic is the so-called dual system of vocational training or firm-based training (Ludwig-Mayerhofer et al. 2011), where trainees gain practical skills in training firms and acquire theoretical knowledge in part-time vocational training schools. Germany's well-known dual training system, in which twothirds of all VET participants were enrolled in 2019 (Bundesinstitut für Berufsbildung 2020) is complemented by a school-based training system, where training takes place in full-time vocational training schools. This school-based training differs in its institutional specifications between the federal states (Daniel et al. 2019). It is quite common for health-related occupations like medical assistants and nurses, as well as for Kindergarten teachers and social workers (Ludwig-Mayerhofer et al. 2011). Graduates from VET receive occupation-specific certificates, which are required in order to work as skilled labor in Germany (e.g., Bol et al. 2019; Graf 2015; Hillmert et al. 2017). The standardization of occupation-specific trainings and certificates enables inter-firm mobility of skilled labor but restricts mobility across occupations. Hence, vocational training decisions have lasting effects on individuals' career prospects (Protsch and Solga 2016).

Occupations can be classified according to the German Classification of Occupations, edition 2010, (KldB 2010) that categorizes them according to their competence profiles and task complexity (Bundesagentur für Arbeit 2011) within a five-digit system. ${ }^{1}$ On the one digit-level, there are 10 occupational segments including military, which is, however, often omitted in statistical representations. This system includes all occupations that require vocational training, academic training and occupations which can be practiced without certified training. Vocational trainings, in turn, are regularly arranged in line with the KldB 2010 (Bundesinstitut für Berufsbildung 2019). In the following, occupational segments are used in order to characterize VET entry fields (see Table 6). ${ }^{2}$

Those secondary school graduates who leave with an LSS degree after nine or ten years of schooling or with an ISS degree after 10 years of schooling usually enter the VET system (Graf 2015). Often the ISS degree is required to begin school-based training (Hillmert et al. 2017; Protsch and Solga 2016). Only graduates who leave school after twelve or thirteen years of schooling with an upper secondary school (USS) degree can enter directly into academic training. The share of graduates with LSS degree has decreased steadily in Germany in the last decades. Together with demographic change this trend contributes to an undersupply of trainees in certain occupations. Figure 1 shows the supply of VET positions relative to 100 applicants where an undersupply of VET positions is indicated by a value below 100 and an oversupply of VET positions by a value above 100. The oversupply of VET positions is greatest in rural regions (Fig. 1).

\footnotetext{
${ }^{1}$ The classification of occupations in the KldB 2010 is based on a horizontal and on a vertical dimension. The horizontal dimension describes the similarity of occupations in their professional requirements, knowledge and skills. The vertical dimension describes the level of requirements in four degrees of complexity and is often associated with a formal educational degree, vocational or academic training certificate (Bundesagentur für Arbeit 2011).

2 We exclude the category military (KldB 2010:0) from the analysis because individuals must be over eighteen to join the military and consequently, this option is not available to all individuals after compulsory schooling.
} 


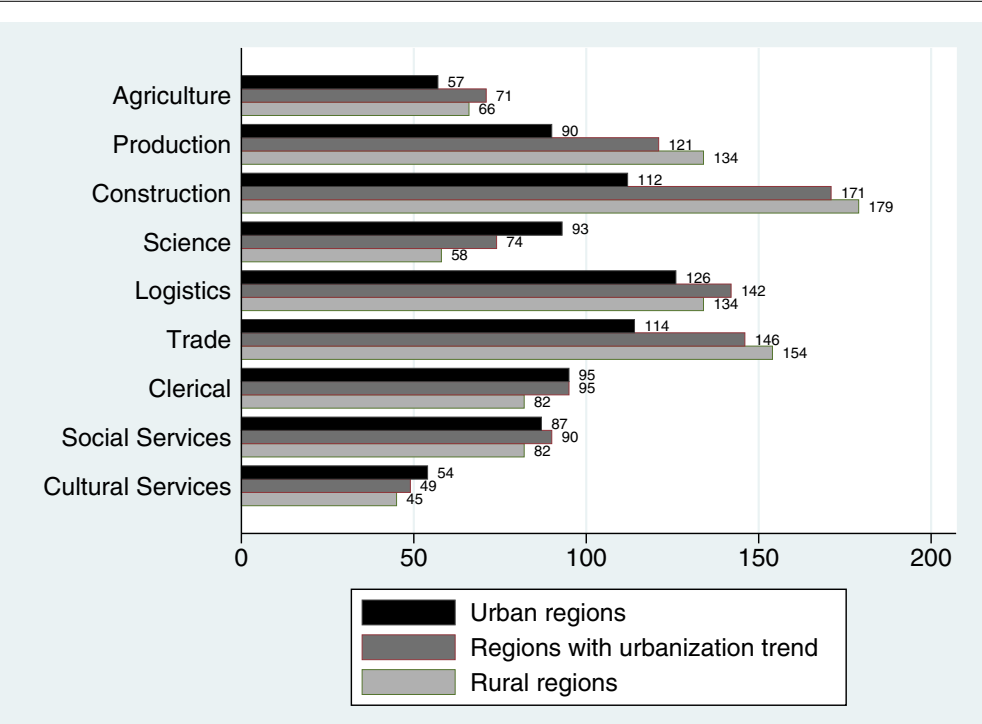

Fig. 1 The relation of vacant VET positions to 100 applicants by occupational segments in 2017/2018. Statistik der Bundesagentur für Arbeit (2019b). The data includes all registered applicants and vacant training positions reported to the Federal Employment Agency. The typology of regions on the level of spatial planning regions by the Federal Institute for Research on Building, Urban Affairs and Spatial Development (BBSR) accounts for population density and settlement structure (Bundesinstitut für Bau-, Stadt- und Raumforschung 2016)

While occupations with an oversupply of VET positions are often characterized by unfavorable working conditions and working hours (Autorengruppe Bildungsberichterstattung 2018; Dummert et al. 2019), an excess demand for training positions can be observed in occupations with favorable working conditions that are frequently characterized by high shares of USS graduates such as in the sciences and in cultural and clerical services (Fig. 2).

The distribution of secondary school graduates across the nine occupational categories corresponds to the different skill requirements of these occupations. LudwigMayerhofer et al. (2011) differentiate between "comparatively simple manual and retail occupations (e.g., bricklayer, painter, or shop assistant)" and "rather complex whitecollar occupations in banking, insurance, and IT, or even personal service occupations (e.g., speech therapist or midwife)". While there are no "official eligibility criteria" for firm-based trainings, individuals with lower skills sort themselves into occupations with lower skill requirements (Heisig and Solga 2015; Levels et al. 2014). Mathematical and literacy skills have generally been shown to influence training decisions and labor market outcomes (Arcidiacono 2004; Volodina and Nagy 2016). Generally, and in line with human capital theory, individuals are inclined to choose vocational trainings in which they have a comparative advantage because they match their skill endowment best (Arcidiacono 2004; Kirkeboen et al. 2016; Pothier 2018). The best matched individuals can expect higher productivity and higher returns to their skills (Bol et al. 2019; Knoll et al. 2017). For Germany, it has been shown that school degrees are of higher relevance than non-documented abilities for applicants' success on the VET market (Protsch and Dieckhoff 2011). Individuals with higher secondary school degrees and higher achieving students generally have better chances in the VET market (Protsch and Solga 2016). 


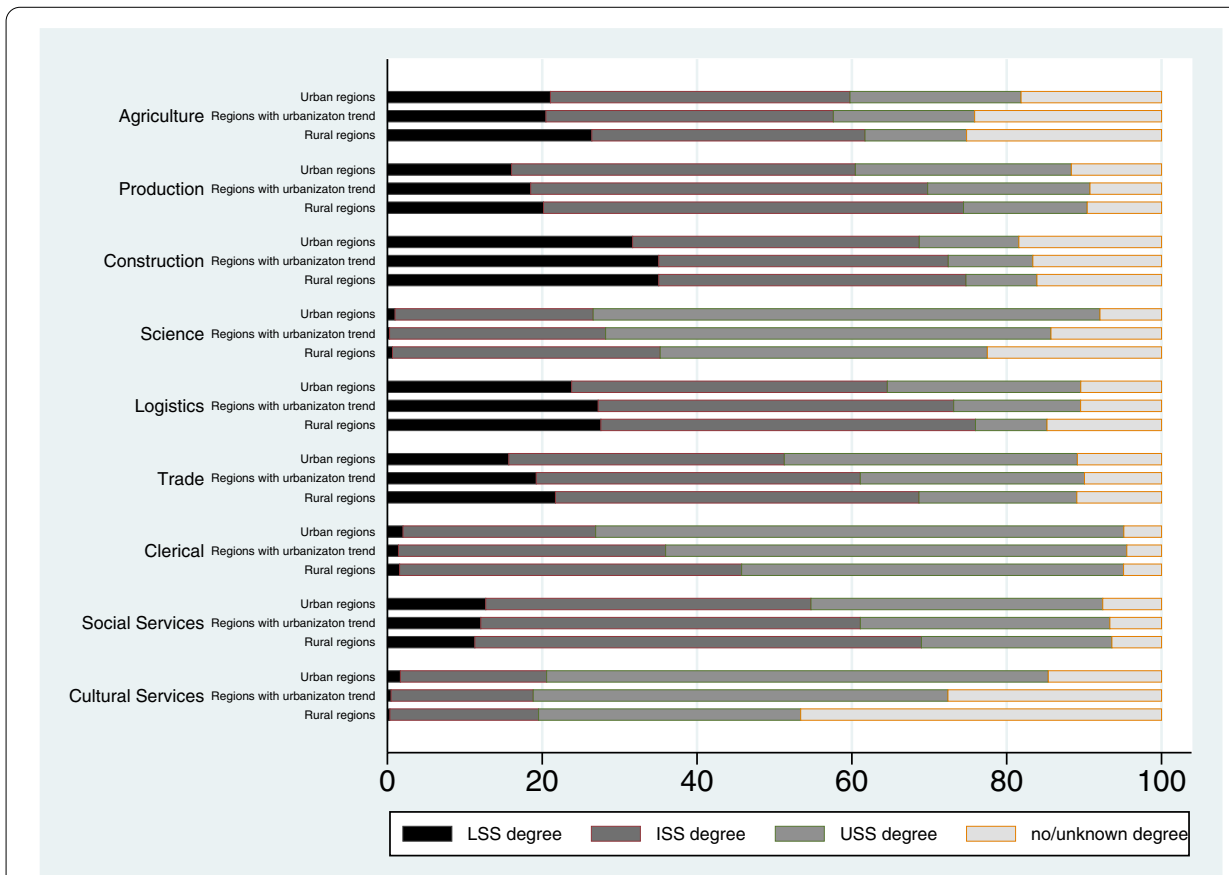

Fig. 2 Share of trainees by KIdB 2010, school degree and type of region in 2017/2018. Data source: (Statistik der Bundesagentur für Arbeit 2019a)

The attractiveness of training positions has been shown to not only be affected by income, employment and promotion prospects (Dummert et al. 2019; Fouarge et al. 2014), but also by non-economic preferences and occupation characteristics (Arcidiacono 2004; Kirkeboen et al. 2016). Individuals consider, for example, aspects like prestige (Heisig and Solga 2015; Reimer and Pollak 2010) and working conditions (Dummert et al. 2019; Ehrenberg and Smith 2017). Expected earnings, perceived ability and individual preferences have been identified as dominant determinants in the choice of college majors (Drost 2002; Montmarquette et al. 2002; Volodina and Nagy 2016; Wiswall and Zafar 2015). While it has to be kept in mind that heterogeneity is large within each occupational segment, occupational qualities can be described in terms of five dimensions (Fig. 3). ${ }^{3}$

Physical demands are specifically high in construction and especially low in science and clerical occupations. Shift work is widespread in production as well as in trade and logistics. Trade and social services are most affected by weekend work. Skill requirements are specifically high in science and clerical occupations, which also benefit from high income potentials.

In order to get an idea of the heterogeneity within occupational segments and of its possible relevance for analyses from a regional perspective, Table 1 provides information on occupations on the two-digit level (occupational main groups) with relevance for

\footnotetext{
$\overline{{ }^{3} \text { We only show the eight categories which are part of our empirical analyses. Thereby, category nine (KldB 2010:9) is }}$ excluded due to too few observations in our sample.
} 


\begin{tabular}{|c|c|c|c|c|c|c|}
\hline & \multirow[t]{2}{*}{ KIdB 2010} & \multicolumn{5}{|c|}{ Working conditions (DGB, Eurofound) } \\
\hline & & \multicolumn{2}{|c|}{ Physical demands } & \multicolumn{2}{|c|}{ Shift work } & Weekend work \\
\hline 1 & Agriculture & & \multirow{2}{*}{$\begin{array}{l}\text { average } \\
\text { average }\end{array}$} & & sometimes & \multirow{8}{*}{$\begin{array}{l}\text { sometimes } \\
\text { rarely } \\
\text { sometimes } \\
\text { sometimes } \\
\text { sometimes } \\
\text { often } \\
\text { rarely } \\
\text { often }\end{array}$} \\
\hline 2 & Production & & & & often & \\
\hline 3 & Construction & & high & & \multirow{2}{*}{$\begin{array}{l}\text { rarely } \\
\text { rarely }\end{array}$} & \\
\hline 4 & Science & & low & & & \\
\hline 5 & Logistics & & average & & often & \\
\hline 6 & Trade & & |average & & often & \\
\hline 7 & Clerical & & low & & rarely & \\
\hline \multirow[t]{2}{*}{$0^{\circ}$} & Social services & & average & & sometimes & \\
\hline & KIdB 2010 & Skill level (BA) & el (BA) & & \\
\hline 1 & Agriculture & average & & \multicolumn{2}{|c|}{$\frac{\text { Income (Destatis) }}{\text { low }}$} & \\
\hline 2 & Production & \multirow{7}{*}{$\begin{array}{r}\text { average } \\
\text { low } \\
\text { high } \\
\text { low } \\
\text { average } \\
\text { high } \\
\text { average }\end{array}$} & & average & & \\
\hline 3 & Construction & & & \multirow{2}{*}{$\begin{array}{r}\text { low } \\
\text { high }\end{array}$} & & \\
\hline 4 & Science & & \multirow{2}{*}{\multicolumn{2}{|c|}{$\begin{array}{r}\text { high } \\
\text { low to average }\end{array}$}} & & \\
\hline 5 & Logistics & & & & & \\
\hline 6 & Trade & & \multicolumn{2}{|c|}{$\begin{array}{r}\text { low to average } \\
\text { average }\end{array}$} & & \\
\hline & Clerical & & & & \\
\hline & Social services & & & & & \\
\hline \multicolumn{7}{|c|}{$\begin{array}{l}\text { Fig. } 3 \text { Characteristics of occupational segments. The labels "average" and "sometimes" describe quality } \\
\text { dimension which correspond to the mean values across all occupational categories. A downward deviation } \\
\text { from the mean is indicated by "low" and "rarely" and an upward deviation by "high"and "often". For further } \\
\text { explanations see "Appendix" Section A4.1. Source: Eurofound 2017; Institut DGB-Index Gute Arbeit 2012, } 2015 \\
\text {;Sächsisches Staatsministerium für Wirtschaft, Arbeit und Verkehr 2018; Statistik der Bundesagentur für Arbeit } \\
\text { 2019c; Statistisches Bundesamt } 2016\end{array}$} \\
\hline
\end{tabular}

VET. Therein, occupational main groups are classified according to the region types in which they tend to be concentrated, if at all (Margarian 2018).

Two third of the trainees from the production segment, where 33.5 percent of all trainees are engaged, belong to the occupational groups $23,25,26$, and 27 . These industries tend to be relatively strong in the urban and peri-urban region types and tend to offer better income opportunities than those production occupations largely concentrated in rural regions. Generally, industries with the highest shares of USS graduates in vocational trainings and the highest lifetime earnings (Stüber 2016) tend to be concentrated in urban regions. From a gross perspective (Table 2), clerical occupations have a relatively low degree of urban concentration given their share of USS graduates and their lifetime income; while trade, with its low degree of spatial concentration, is relatively attractive for USS graduates despite its low lifetime income.

\section{Literature review and theoretical framework: the regional perspective}

With restricted information and mobility (Green and White 2008; Sewell and Orenstein 1965), or respectively with information costs (Ehrenberg and Smith 2017; Halpern and Stern 1998; Knoll et al. 2017), the graduates' occupational segment of VET entry does not only depend on individual characteristics but also on the local labor market. Various authors confirm that the likelihood that an individual will participate in education and training decreases as mobility costs increase with distance to educational institutions (e.g., Falch et al. 2013; Frenette 2004; Spiess and Wrohlich 2010). With regard to VET choices, mobility is specifically restricted due to the usually young age of individuals that increases their dependence on family support (Bradley and Taylor 2004; Tumino 2013) as well as on the public transport system (Weßling et al. 2015). 
Table 1 Relevant occupational characteristics by typical location type

\begin{tabular}{|c|c|c|c|c|c|c|c|}
\hline \multirow{2}{*}{$\begin{array}{l}\text { Occupational } \\
\text { segment }\end{array}$} & \multirow[t]{2}{*}{ Share in total } & \multicolumn{3}{|c|}{$\begin{array}{l}\text { Occupational main } \\
\text { group }\end{array}$} & \multirow[t]{2}{*}{$\begin{array}{l}\text { Share } \\
\text { in segment }\end{array}$} & \multirow[t]{2}{*}{$\begin{array}{l}\text { Share of USS } \\
\text { graduates } \\
\text { in VET }\end{array}$} & \multirow[t]{2}{*}{$\begin{array}{l}\text { Lifetime } \\
\text { income (1000€) } \\
\text { of skilled labor }\end{array}$} \\
\hline & & & & & & & \\
\hline \multirow[t]{2}{*}{2} & Production & 33.5 & 27 & $\begin{array}{l}\text { Technical } \\
\text { research and } \\
\text { development, } \\
\text { construction, } \\
\text { and produc- } \\
\text { tion planning } \\
\text { and schedul- } \\
\text { ing }\end{array}$ & 5 & 48 & 1716 \\
\hline & & & 23 & $\begin{array}{l}\text { Paper-making } \\
\text { and -process- } \\
\text { ing, printing, } \\
\text { and in techni- } \\
\text { cal media } \\
\text { design }\end{array}$ & 3 & 47 & 1459 \\
\hline \multirow[t]{2}{*}{3} & Construction & 8.6 & 31 & $\begin{array}{l}\text { Construction } \\
\text { scheduling, } \\
\text { architecture } \\
\text { and surveying }\end{array}$ & 2 & 62 & 1623 \\
\hline & & & 34 & $\begin{array}{l}\text { Building services } \\
\text { engineering } \\
\text { and technical } \\
\text { building } \\
\text { services }\end{array}$ & 42 & 10 & 1367 \\
\hline \multirow[t]{2}{*}{4} & Science & 4.7 & 43 & $\begin{array}{l}\text { Computer sci- } \\
\text { ence, informa- } \\
\text { tion and com- } \\
\text { munication } \\
\text { technology }\end{array}$ & 69 & 61 & 2175 \\
\hline & & & 41 & $\begin{array}{l}\text { Mathemat- } \\
\text { ics, biology, } \\
\text { chemistry and } \\
\text { physics }\end{array}$ & 28 & 50 & 1837 \\
\hline \multirow[t]{3}{*}{5} & Logistics & 6.0 & 51 & $\begin{array}{l}\text { Traffic and } \\
\text { logistics (with- } \\
\text { out vehicle } \\
\text { driving) }\end{array}$ & 75 & 23 & 1431 \\
\hline & & & 53 & $\begin{array}{l}\text { Safety and } \\
\text { health protec- } \\
\text { tion, security } \\
\text { and surveil- } \\
\text { lance }\end{array}$ & 6 & 17 & 1259 \\
\hline & & & 54 & $\begin{array}{l}\text { Cleaning ser- } \\
\text { vices }\end{array}$ & 3 & 3 & 992 \\
\hline 6 & Trade & 16.9 & 61 & $\begin{array}{l}\text { PURCHASING, } \\
\text { sales and } \\
\text { trading }\end{array}$ & 20 & 57 & 1782 \\
\hline \multirow[t]{2}{*}{7} & Clerical & 16.9 & 72 & $\begin{array}{l}\text { Financial ser- } \\
\text { vices, account- } \\
\text { ing and tax } \\
\text { consultancy }\end{array}$ & 24 & 70 & 2084 \\
\hline & & & 71 & $\begin{array}{l}\text { Business man- } \\
\text { agement and } \\
\text { organisation }\end{array}$ & 54 & 53 & 1629 \\
\hline
\end{tabular}


Table 1 (continued)

\begin{tabular}{|c|c|c|c|c|c|c|c|}
\hline \multirow{2}{*}{$\begin{array}{l}\text { Occupational } \\
\text { segment }\end{array}$} & \multirow{2}{*}{$\begin{array}{l}\text { Share in total } \\
\text { Cultural }\end{array}$} & \multicolumn{3}{|c|}{$\begin{array}{l}\text { Occupational main } \\
\text { group }\end{array}$} & \multirow{2}{*}{$\begin{array}{l}\begin{array}{l}\text { Share } \\
\text { in segment }\end{array} \\
26\end{array}$} & \multirow{2}{*}{$\begin{array}{l}\text { Share of USS } \\
\text { graduates } \\
\text { in VET }\end{array}$} & \multirow{2}{*}{$\begin{array}{l}\text { Lifetime } \\
\text { income (1000€) } \\
\text { of skilled labor }\end{array}$} \\
\hline & & 1.5 & 94 & $\begin{array}{l}\text { The performing } \\
\text { arts and enter- } \\
\text { tainment }\end{array}$ & & & \\
\hline & & & 92 & $\begin{array}{l}\text { Advertising and } \\
\text { marketing, in } \\
\text { commercial } \\
\text { and editorial } \\
\text { media design }\end{array}$ & 44 & 69 & 1393 \\
\hline & & & 93 & $\begin{array}{l}\text { Product design, } \\
\text { artisan craft- } \\
\text { work, fine arts } \\
\text { and the mak- } \\
\text { ing of musical } \\
\text { instruments }\end{array}$ & 29 & 42 & 1220 \\
\hline \multicolumn{8}{|l|}{ Peri-urban } \\
\hline \multirow[t]{2}{*}{2} & Production & 33.5 & 25 & $\begin{array}{l}\text { Machine- } \\
\text { building and } \\
\text { automotive } \\
\text { industry }\end{array}$ & 32 & 14 & 1617 \\
\hline & & & 26 & $\begin{array}{l}\text { Mechatron- } \\
\text { ics, energy } \\
\text { electronics } \\
\text { and electrical } \\
\text { engineering }\end{array}$ & 26 & 25 & 1587 \\
\hline \multicolumn{8}{|l|}{ Rather rural } \\
\hline \multirow[t]{2}{*}{1} & Agriculture & 2.6 & 12 & $\begin{array}{l}\text { Horticulture and } \\
\text { floristry }\end{array}$ & 52 & 18 & 1147 \\
\hline & & & 11 & $\begin{array}{l}\text { Agriculture, } \\
\text { forestry, and } \\
\text { farming }\end{array}$ & 48 & 24 & 1083 \\
\hline \multirow[t]{4}{*}{2} & Production & 33.5 & 21 & $\begin{array}{l}\text { Production and } \\
\text { processing of } \\
\text { raw materials, } \\
\text { glass- and } \\
\text { ceramic- } \\
\text { making and } \\
\text {-processing }\end{array}$ & 1 & 15 & 1445 \\
\hline & & & 22 & $\begin{array}{l}\text { Plastic-making } \\
\text { and -process- } \\
\text { ing, and } \\
\text { wood-working } \\
\text { and -process- } \\
\text { ing }\end{array}$ & 8 & 19 & 1329 \\
\hline & & & 28 & $\begin{array}{l}\text { Textile- and } \\
\text { leather- } \\
\text { making and } \\
\text {-processing }\end{array}$ & 1 & 26 & 1147 \\
\hline & & & 29 & $\begin{array}{l}\text { Food-produc- } \\
\text { tion and } \\
\text {-processing }\end{array}$ & 9 & 16 & 1124 \\
\hline 3 & Construction & 8.6 & 32 & $\begin{array}{l}\text { Building } \\
\text { construction } \\
\text { above and } \\
\text { below ground }\end{array}$ & 25 & 9 & 1366 \\
\hline 6 & Trade & 16.9 & 63 & $\begin{array}{l}\text { Tourism, hotels } \\
\text { and restau- } \\
\text { rants }\end{array}$ & 21 & 35 & 965 \\
\hline
\end{tabular}


Table 1 (continued)

\begin{tabular}{|c|c|c|c|c|c|c|c|}
\hline \multirow{2}{*}{$\begin{array}{l}\text { Occupational } \\
\text { segment } \\
\text { Rather all-over }\end{array}$} & \multirow[t]{2}{*}{ Share in total } & \multicolumn{3}{|c|}{$\begin{array}{l}\text { Occupational main } \\
\text { group }\end{array}$} & \multirow[t]{2}{*}{$\begin{array}{l}\text { Share } \\
\text { in segment }\end{array}$} & \multirow[t]{2}{*}{$\begin{array}{l}\text { Share of USS } \\
\text { graduates } \\
\text { in VET }\end{array}$} & \multirow[t]{2}{*}{$\begin{array}{l}\text { Lifetime } \\
\text { income }(1000 €) \\
\text { of skilled labor }\end{array}$} \\
\hline & & & & & & & \\
\hline 2 & Production & 33.5 & 24 & $\begin{array}{l}\text { Metal-making } \\
\text { and -working, } \\
\text { and in metal } \\
\text { construction }\end{array}$ & 17 & 12 & 1535 \\
\hline 3 & Construction & 8.6 & 33 & $\begin{array}{l}\text { Interior con- } \\
\text { struction }\end{array}$ & 30 & 10 & 1272 \\
\hline 5 & Logistics & 6.0 & 52 & $\begin{array}{l}\text { Drivers and } \\
\text { operators of } \\
\text { vehicles and } \\
\text { transport } \\
\text { equipment }\end{array}$ & 15 & 10 & 1194 \\
\hline 6 & Trade & 16.9 & 62 & Retail trade & 58 & 18 & 1187 \\
\hline 7 & Clerical & 16.9 & 73 & $\begin{array}{l}\text { Law and public } \\
\text { administration }\end{array}$ & 22 & 57 & 1607 \\
\hline \multirow[t]{3}{*}{8} & Social & 9.4 & 83 & $\begin{array}{l}\text { Education and } \\
\text { social work, } \\
\text { housekeeping, } \\
\text { and theology }\end{array}$ & 5 & 2 & 1464 \\
\hline & & & 81 & $\begin{array}{l}\text { Medical and } \\
\text { health care } \\
\text { occupations }\end{array}$ & 63 & 17 & 1335 \\
\hline & & & 82 & $\begin{array}{l}\text { Non-medical } \\
\text { healthcare, } \\
\text { body care, } \\
\text { wellness and } \\
\text { medical tech- } \\
\text { nicians }\end{array}$ & 32 & 23 & 1108 \\
\hline
\end{tabular}

The segments of occupational main groups with $15 \%$ or more of all trainees in the segment. Sources: Statistisches Bundesamt (2019b), Stüber (Stüber), Statistik der Bundesagentur für Arbeit (2015)

Table 2 Characteristics on segment level by weighted group characteristics

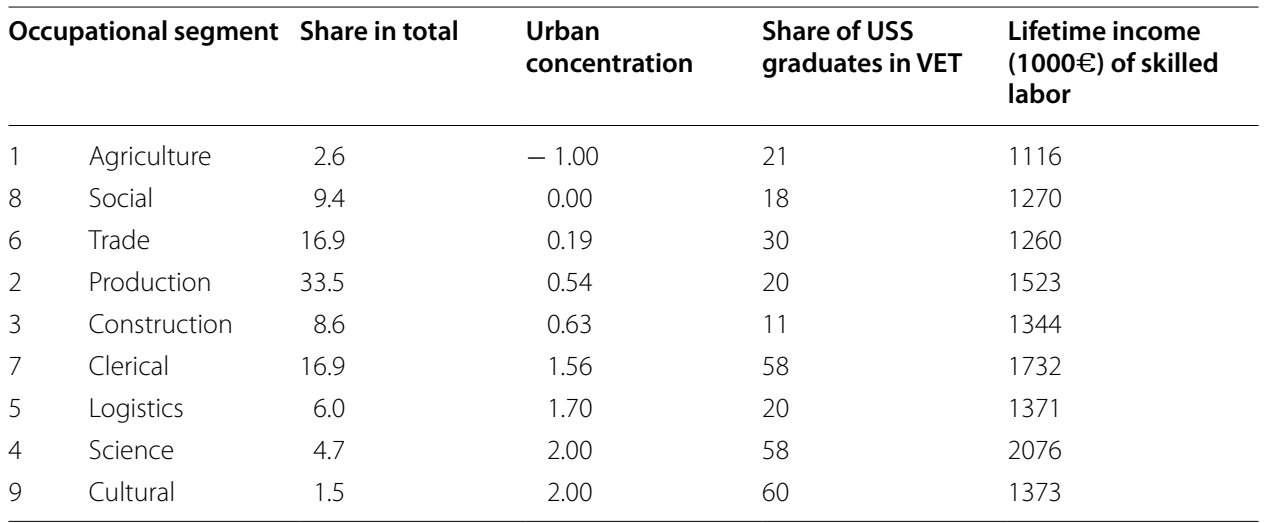

For the calculation of "urban concentration", the category "rather urban" has been ascribed the value 2, rather peri-urban the value 1, rather all-over the value 0 , and rather rural the value -1 (compare Table 1). Then the weighted mean has been calculated across a segment's main groups

See Table 1 
Kleinert et al (2018) identify the cohort size, the share of USS graduates, the unemployment rate, the employment share of the secondary sector and the number of large training establishments in a region as important potential determinants of matching processes and training choices in their classification of VET markets. At hand of the clusters they create, the authors find "a clear distinction between metropolitan, urban and rural training markets" (Kleinert et al. 2018). Generally, labor markets can be characterized by their opportunity structures (Glauser and Becker 2016; Green and White 2008). From the perspective of graduates looking for training positions, the opportunity structure is determined by available training positions and career prospects. As the cohort size in Kleinert et al. (2018) indicates, competition for training positions may be a third relevant VET market characteristic. Diversity and density of local labor markets are crucial conditions for all three determinants.

\section{Supply of training positions}

Educational decisions have generally been shown to depend on the regional infrastructure of educational institutions due to mobility costs (Ditton 1992). The supply of VET positions depends on the number of firms that participate in the dual system; and it depends on the location of vocational schools that offer school-based training. With respect to the locations and local specificities of educational institutions little systematic knowledge exists due to the large variety and institutional diversity of school-based training in Germany (Seeber and Michaelis 2015). Nevertheless, as the local demand for graduates is important for trainees and school operators alike, opportunities for schoolbased training can be assumed to be better in diverse urban than in smaller rural labor markets.

With respect to firm-based training, a large labor pool improves the match between training firms and trainees (Bleakley and Lin 2012; Bolder 1975). Dense urban labor markets are characterized by a higher level of economic activities and a higher degree of industrial diversity (Karlsson and Pettersson 2005) than thin rural labor markets. Individuals on the peripheries either have to adapt to the narrowed range of vocational trainings or have to commute or migrate for their desired vocational training (e.g. Wochnik 2014). Moreover, individuals growing up in urban areas with diverse labor markets tend to be better informed about the spectrum of occupational possibilities than individuals from rural areas (Sewell and Orenstein 1965). Nevertheless, it has been demonstrated that firms that have to bear the costs of general education for their trainees offer fewer training positions in dense labor markets with a high danger of labor poaching (Muehlemann and Wolter 2011). Similarly, the chances for entering the VET system of individuals with LSS degree compared to graduates with higher school degrees has also been found to be reduced in regions with high unemployment (Weßling et al. 2015), which can be explained by the high labor supply in these predominantly urban regions. Consequently, with respect to the availability of training positions in firms, labor market diversity can be expected to be of higher relevance than labor market density.

P1a: Compared to rather homogeneous or rural labor markets, diverse or urban labor markets allow for better matches between graduates' abilities on the one hand and vocational trainings' demands on the other hand. 
P1b: Compared to rather homogeneous or rural labor markets, diverse or urban labor markets allow for better matches between graduates' preferences on the one hand, and occupational characteristics on the other hand.

\section{Career prospects}

Local conditions not only shape people's expectations about the chances of success in different training alternatives (Hillmert et al. 2017) but also about the subsequent employment opportunities. Therefore, the relevant opportunity structure is not only defined by the training infrastructure but also by career prospects. Weishaupt (2018) consequently asks whether factors aside from the social composition of the population and the local training infrastructure contribute to regional differences in occupational attainment. Raffe and Willms (1989) confirm that not only unemployment but also industry and occupation structures matter in regional educational and occupational attainment. Graduates' limited mobility and information, and VET's occupational specificity with the resulting limited mobility across occupations, together imply that local industry structure should have a strong impact on career prospects that are opened up by specific vocational trainings. The local occupation structure should then have a direct effect upon school graduates' occupational segment of VET entry.

P2: Where attractive occupational segments have a high share in the work force, graduates have an increased likelihood of entering related vocational trainings.

\section{Competition on the VET market}

A higher density of economic activities is not only usually associated with more diversity and a better opportunity structure but also with higher competition on the labor market (Di Addario 2011). Even if the opportunity structure is good, individuals might still not be able to realize their primary VET choices if local demand for specific training positions exceeds the local supply of these positions. As employers choose their trainees in the German dual training system, the competition on the VET market is comparable to the situation on the general labor market (Weßling et al. 2015). Consequently, the link between VET entries and the local labor market situation can be expected to be especially close in the dual system (ibid.).

Competition for training positions for the most attractive occupations with the best career prospects results in a stratification of vocational trainings by educational attainment (Protsch and Solga 2016). It has also been shown, however, that the appraisal of secondary school degrees depends on the graduates' composition in a region (Protsch and Dieckhoff 2011). Dummert et al. (2019) confirm that the availability of school graduates and the competition within regions and sectors affect the recruiting success of firms and thereby the quality of matches on the VET market. Local graduates looking for training positions face specifically strong competition in those urban regions that attract applicants from other regions (Eberhard 2012). In fact, USS graduates have in almost all vocational trainings a higher share in urban than in rural regions (see Fig. 2). A stronger selection based on ability is therefore to be expected in urban regions with a higher share of USS graduates (e.g., Bundesinstitut für Bau-, Stadt- und Raumforschung 2019; Sixt 2010). 


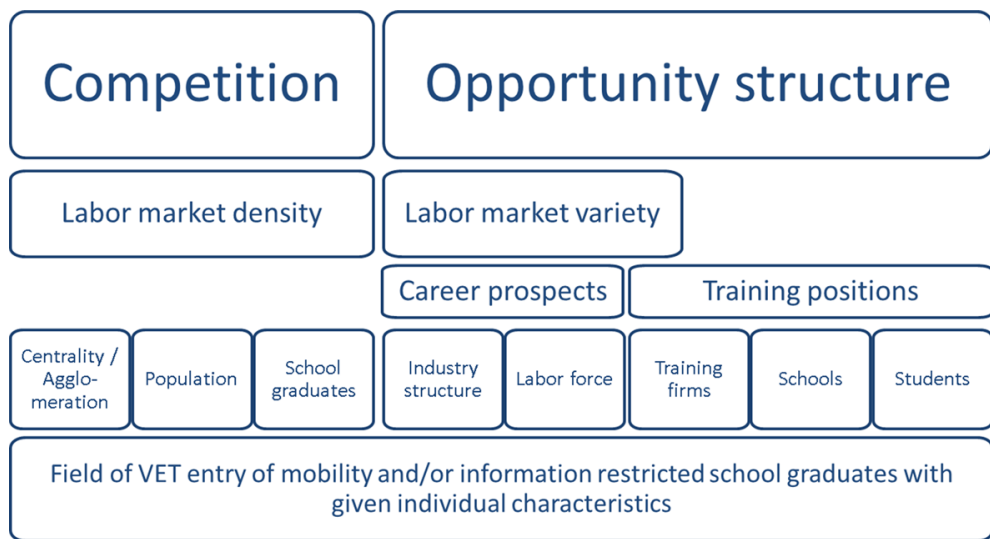

Fig. 4 Conceptual frame. Source: Own figure

P3a: Graduates with lower documented abilities have a lower likelihood of entering the most attractive occupation segments in competitive urban than in rural VET markets.

Consequently, even though it is generally expected that diverse, urban labor markets offer more opportunities for the realization of individual preferences (see P1b), LSS and ISS graduates might have a reduced likelihood of realizing certain preferences in urban areas.

P3b: For graduates with lower documented abilities the likelihood of realizing certain preferences might be higher in non-competitive rural VET markets than in urban labor markets.

\section{Conceptual framework and hypotheses}

Figure 4 summarizes the core arguments from the literature review. Together with the derived propositions, it describes the conceptual foundation of the empirical analysis. At its core is the potential ambiguity in urban labor markets' effect on immobile graduates' ability to realize their preferences that is due to the countervailing effects of opportunity structure (diversity) vs. competition (density).

Due to this ambiguity, the two preference-related propositions P1b (opportunity structure/diversity argument) and P3b (competition/density argument) are partially antagonistic. The antagonism may be resolved by the additional consideration of occupations' characteristics. Graduates without USS degree under certain conditions have better opportunities to realize specific preferences in diverse urban than in homogenous rural VET markets. This is for example the case if the relevant occupation segments' most attractive training places concentrate in urban labor markets but have a low attractiveness for USS graduates. This applies to the production segment (see Table 1)

H1a: Graduates without USS degree have a higher likelihood of realizing economic preferences within the production segment in urban than in rural regions.

If preference realization requires enrollment in occupation segments that are concentrated in urban regions, the opportunity structure argument might prevail as well, independently from competition. 
H1b: Even graduates without USS degree possibly have a higher likelihood of realizing economic and comfort preferences within the science segment in urban than in rural regions.

The social segment has neither a high share of USS graduates, nor is it concentrated in urban regions. Consequently, the relation between social preferences and the likelihood of entering the social segment is expected to be relatively unaffected by location:

H1c: Graduates without USS degree and a social orientation generally have an increased likelihood of entering VET in the social segment.

The general expectation expressed by proposition P1b, that diverse labor markets provide better opportunities for the realization of preferences, is difficult to assess more directly on the level of occupation segments because the relevant diversity becomes more visible at a more detailed classification level of occupations (compare Table 1). We know, however, that sub-segment diversity is lower in rural than in urban regions. Consequently, rural regions provide generally fewer alternatives for the realization of given preferences. Therefore, preferences that can principally be realized anywhere are expected to cause a stronger concentration on well-suited occupation segments in rural than in diverse urban labor markets.

H1d: The likelihood for graduates without USS degree with social orientation or comfort preferences of entering VET in the social, respectively the clerical, segment is higher in more homogenous rural than in diverse urban regions.

The competition argument may be assessed at hand of preferences whose realization requires enrollment in training segments whose attractiveness for USS graduates is high (see Table 2). If respective training opportunities are available all-over and not concentrated in urban regions graduates with lower documented abilities have better chances for the realization of specific preferences in rural regions with low in-migration.

H1e: Graduates without USS degree have a higher likelihood of realizing economic and comfort preferences within the clerical segment in rural than in urban regions.

The two ability-related propositions P1a (opportunity structure/diversity) and P3a (competition/density) are not antagonistic. They rather describe two different mechanisms that contribute both to a stronger match on ability in urban and a weaker match on ability in rural locations. In line with the expectation of P3a that the likelihood of entering the most attractive vocational trainings is generally restricted for graduates without USS degree in urban locations with strong competition by USS graduates, we derive the following hypothesis:

H2a: ISS graduates' advantage over LSS graduates in terms of entering VET in the most attractive science and clerical segments is lower in urban than in rural labor markets.

Given the relatively high attractiveness of the production segment for non-USS graduates in urban as compared to rural labor markets, we additionally derive the following hypothesis:

H2b: In urban, but not in rural labor markets, ISS graduates have a higher likelihood of entering the production segment than LSS graduates.

With respect to diversity's role (P1a) we can apply the argument that substantiates the preference-related H1d with respect to ability as well: As less diverse and more rural regions provide generally fewer alternatives for the realization of high abilities, higher abilities are expected to cause a stronger concentration on well-suited occupation segments that are 
abundant there than in more diverse or urban labor markets. Many attractive occupations that are available almost everywhere belong to the clerical occupation segment.

H2c: The positive effect of having an ISS rather than an LSS degree on the likelihood of entering the attractive clerical segment is stronger in more homogenous (rural) than in diverse (urban) labor markets.

Expectations that relate to proposition P2 on the direct relationship between the local occupation structure (career prospects) and graduates' preferred segments of VET entry can further be qualified through recognition of the most attractive vocational trainings as measured by shares of USS graduates and lifetime incomes (see Table 2):

H3: Where the production, science, or clerical segments comprise high shares of the work force, graduates have an increased likelihood of entering related vocational trainings.

\section{Method and data}

Empirically, we analyze the direct relation between local labor market conditions and the occupational segment of VET entry as well as the moderating effect of local labor market conditions on the match between individuals' abilities and preferences on the one hand, and the occupational segment of VET entry on the other hand. Our focus is on the short-term gross relationship between VET entry segments on the one hand, and labor market density and diversity on the other hand.

The empirical analysis relies on data from the NEPS, a representative German longterm panel survey on individuals' education processes with different starting cohorts. ${ }^{4}$ The NEPS data itself includes information about individuals` vocational training, socioeconomic background and education. ${ }^{5}$ Our data set is based on information from questionnaires ${ }^{6}$ and from competence tests. The analysis exploits self-reported preferences and abilities as measured by grades, school-leaving certificates, and additional tests. Thereby, possible effects of the population's self-selection or of endogenous preference formation are controlled but not scrutinized further.

Included in the analysis are only LSS and ISS graduates from the NEP's starting cohort four (SC4), which started in 2010 and was conducted with ninth graders, tracking their schooling and post-schooling choices. ${ }^{7}$ This cohort captures the transition from compulsory schooling to further education, vocational training and entry into the labor market (Blossfeld et al. 2011).

We use data provided in theNEPS waves one to nine to conduct a cross-sectional analysis in which we pool a sample of students who enter vocational training after obtaining

\footnotetext{
${ }_{4}^{4}$ This paper uses data from the National Educational Panel Study (NEPS): Starting Cohort Grade 9, doi:10.5157/ NEPS:SC4:9.1.1. From 2008 to 2013, NEPS data was collected as part of the Framework Program for the Promotion of Empirical Educational Research funded by the German Federal Ministry of Education and Research (BMBF). As of 2014, NEPS is carried out by the Leibniz Institute for Educational Trajectories (LIfBi) at the University of Bamberg in cooperation with a nationwide network.

${ }^{5}$ Definitions and descriptions of all exogenous variables are provided in the tables in the Appendix along with descriptive statistics by vocational training choice for individual and family characteristics (see Tables 7,8). Related questions from the NEPS survey are documented in Table 9.

${ }^{6}$ If individuals in the NEPS did not provide information for the variables of interest themselves, the missing values are filled in, where possible, with data provided by the parent's questionnaire.

7 SC4 offers data for individuals on regular schools and special needs schools, but only individuals that attended regular schools are considered in the analysis.
} 
their final school degree. ${ }^{8}$ Thereby, we concentrate on vocational trainings leading to full occupation-specific qualification and on graduates with LSS and ISS degree $(\mathrm{N}=4502)$. We have complete information for 3403 individuals. ${ }^{9}$ Concentration on LSS and ISS graduates prevents a potential selection bias as USS graduates have academic training as additional option. In the context of the German education system, the concentration on LSS and ISS graduates allows for a relatively clear analytical separation between vertical education level decisions and horizontal vocational training choices. ${ }^{10}$

The NEPS data are combined with regional data on the level of spatial planning regions (ROR) at the secondary school location from different sources (see Tables 7, 8, 9). School location is a reasonable choice given that the school context has been shown to have a much higher influence on individuals' occupational aspirations than their neighborhood (Wicht and Ludwig-Mayerhofer 2014). Moreover, on the level of ROR, school location and place of residence is identical in the vast majority of cases. ROR are defined under consideration of commuting patterns (Bundesinstitut für Bau-, Stadt- und Raumforschung 2017) below the level of federal states but above the district level, representing the German NUTS3 regions. Their borders can be expected to be rarely crossed by young school graduates in the context of VET entry. Relative immobility of LSS and ISS graduates and the use of ROR minimize the potential bias that could be caused if the opportunity structure at the graduates' initial place of residence is of minor importance for mobile individuals or if the characteristics of neighboring geographical units are of high relevance for (certain) residents of certain geographical units. As Weßling et al. (2015) have shown in the context of school-to-work transitions, in analyses on the district level it would be necessary to take the situation in neighboring districts into account.

The final sample includes 3403 individuals who enter vocational training after graduating from LSS and ISS. Information on occupational preferences is only available for a sub-sample that consists of individuals with an ISS degree. ${ }^{11}$ The sub-sample contains 1897 individuals compared to the 3403 individuals of the full-sample model. As a robustness check, we estimated the basic model without preferences for the full- and the subsample and obtained stable results with regard to our research questions.

Because the occupational segments of VET entry are horizontally differentiated in unordered categories, a multinomial logit (MNL) model is applied that assumes that individuals enter the vocational training that maximizes their utility given the individual and regional restrictions. In the model, individual-specific covariates are captured by the vector $x_{i}$. Common local labor market characteristics $z_{r}$ of individuals that are located within a common region $r$ potentially create regional covariance of observations. This is taken into account by clustered standard errors. The maximum likelihood estimation

\footnotetext{
${ }^{8}$ As our sample consists only of students in vocational training, the provided weights in the NEPS data set are not suitable for our analysis as the correspond to all students in grade 9 and not to all students in vocational training (Steinhauer and Zinn 2016).

${ }^{9}$ Cases with missing values are discarded. We did not impute data due to the fact that the imputation procedures of polynomial variables are not as progressive as for continuous data (Volodina and Nagy 2016)

10 We also conducted our analyses with a sample which included graduates with all three secondary school degrees, which shows similar results regarding our research questions and are provided by request

11 This is due to the fact that the instrument was only introduced into the questionnaire for students at a later point of time, when many LSS graduates had already left school and were subject to a different questionnaire.
} 
Table 3 Descriptive statistics of the dependent variable

\begin{tabular}{|c|c|c|c|c|c|c|c|}
\hline & & \multicolumn{2}{|l|}{ All } & \multicolumn{2}{|c|}{ Female } & \multicolumn{2}{|l|}{ Male } \\
\hline & & $\mathbf{N}$ & $\%$ & $\mathrm{~N}$ & $\%$ & $\mathrm{~N}$ & $\%$ \\
\hline \multicolumn{8}{|c|}{ KldB 2010} \\
\hline 1 & Agriculture & 70 & 2.06 & 19 & 1.28 & 51 & 2.66 \\
\hline 2 & Production & 1137 & 33.42 & 127 & 8.53 & 1010 & 52.77 \\
\hline 3 & Construction & 241 & 7.08 & 10 & 0.67 & 231 & 12.07 \\
\hline 4 & Science & 157 & 4.61 & 25 & 1.68 & 131 & 6.90 \\
\hline 5 & Logistics & 5133 & 3.91 & 19 & 1.28 & 114 & 5.96 \\
\hline 6 & Trade & 431 & 12.67 & 274 & 18.40 & 157 & 8.20 \\
\hline 7 & Clerical & | 405 & 11.90 & 292 & 19.61 & 113 & 5.90 \\
\hline 8 & Social services & 829 & 24.36 & 723 & 48.56 & 106 & 5.54 \\
\hline Total & & 3403 & 100 & 1489 & 100 & 1914 & 100 \\
\hline
\end{tabular}

Data source: NEPS, SC4

determines individual level coefficients $\beta_{j}$ and region level coefficients $\gamma_{j}$. The probability $p_{i j}$ that individual $i$ enters the occupational alternative $j$ subject to constraints can be calculated as (e.g. Cameron and Trivedi 2009).

$$
P_{i j}=\frac{\exp \left(\boldsymbol{x}_{i} \boldsymbol{\beta}_{j}+\boldsymbol{z}_{r(i)} \boldsymbol{\gamma}_{j}\right)}{\sum_{j=1}^{J} \exp \left(\boldsymbol{x}_{i} \boldsymbol{\beta}_{j}+\boldsymbol{z}_{r(i)} \boldsymbol{\gamma}_{j}\right)}, \mathrm{j}=1, \ldots \mathrm{J}
$$

\section{Outcome variable}

The dependent variable describes the graduates' occupational segment of VET entry that is defined on the level of occupation segments (KldB 210:1-8) (see Table 6). We excluded the occupational segment cultural service (KldB 2010: 9) in our analyses because of too few observations in this category. The occupational segment agriculture is included in the analysis but not further interpreted, because its small size and specific characteristics make the interpretation rather irrelevant and problematic.

A majority of the individuals in our sample enter vocational training in production and social services (Table 3). Vocational training in clerical occupations or in trade is relatively frequent as well. Only relatively small shares of school graduates enroll in agriculture, science and logistics. In accordance with the general statistics (Statistik der Bundesagentur für Arbeit 2019c), vocational training in production and construction attracts more men than women, whereas the opposite applies to vocational training in social services and, to a lower degree, in clerical occupations. We refrain from a separate estimation by gender as in that case some occupational categories would only be sparsely occupied due to the partial complementarity of VET choices between men and women.

\section{Explanatory variables}

We use four ability indicators to assess the relationship between ability and vocational training choice and its moderation by local labor market conditions: The secondary school degree, the overall grade on the graduation certificate, as well as estimated scores 
for mathematical and reading competence. ${ }^{12}$ The secondary school degree and the overall grade have been shown to influence individuals' chances to enter specific vocational training (Fouarge et al. 2014; Protsch and Dieckhoff 2011; Somers et al. 2019). School grades range from one (excellent) to six (failed). Grades are used as ability indicator in the subsample with graduates with ISS degree only, while competence scores allow for a measurement of ability independently of the secondary school degree.

With respect to individuals' general preferences for occupational characteristics, the survey includes an instrument that measures preferences for comfort aspects, economic aspects, and social orientation on a scale from one to six (see Tables 8 and 9). Economic aspects, for example, include the items good pay, high job security and good promotion aspects, while comfort aspects cover the items pleasant working hours and good physical working conditions.

All regional variables are standardized in order to ease interpretation. The local occupational structure is described by the local share of employees in the occupation segments (KldB 2010: 1-8). In order to approximate labor market density and diversity, which relate closely to the local settlement structure, we apply the respective typology of the BBSR (Bundesinstitut für Bau-, Stadt- und Raumforschung 2016), and distinguish between urban regions, regions with urbanization trend and rural regions (for further information see Bundesinstitut für Bau-, Stadt- und Raumforschung 2016).

The Simpson or Herfindahl Index has been calculated as a diversity measure from the regional employment shares by occupational segments. It takes on a maximum of 1 if all employment is concentrated in one occupational segment. Its minimum value of $1 / 9$ is applied if employment is perfectly diversified, that is, equally distributed across all nine occupational segments (see for example Simon 1988). As production generally makes up for the largest employment shares among occupation segments, locations that are relatively strong in production tend to have a low diversity. Diversity will be high, in contrast, in locations where the generally smallest segments, specifically agriculture and science (see Table 2), have relatively high shares.

\section{Control variables}

The unemployment rate is included as important regional control for potentially influential labor market characteristics that might be correlated with local labor market density and diversity (Dummert et al. 2019; Hillmert et al. 2017; Pätzold 2008). The supplydemand-relation on the VET market more directly controls occupational opportunities for applicants (Dummert et al. 2019). The share of USS graduates is included as an, albeit imperfect, control for competition on the VET market from this otherwise unobserved group. ${ }^{13}$

In order to control household income, we included an indicator from the survey that consists of three income categories: below $1500 €, 1500 €-3000 €$, above $3000 €$ (see

\footnotetext{
${ }^{12}$ NEPS provides estimated competence scores for reading and mathematics competence. The weighted maximum likelihood estimates (WLE) express competence scores for each individual (for more information see Pohl and Carstensen 2012). They are constrained to have a mean of zero, hence values below zero indicate abilities below average and above zero above average (Pohl and Carstensen 2012).

13 The models have also been estimated without the supply-demand-relation on the VET market and the share of USS graduates in order to check against overcontrol. There were, however, no indications for overcontrol in the results, i.e., inclusion of the controls rather seemed to support the identification of those effects that are in the focus of interest here.
} 
Table 9). We transformed the ordinal scale to a metric scale by multiplying the highest income class by the factor 1.5 and the lowest income category by the factor 0.75 and using the average value of 2250 for the intermediate income category (GESIS-LeibnitzInstitut für Sozialwissenschaften). Based on additional information on the household size, the number of persons under 14 years in the household and the household income, we calculated the equivalized household income that accounts for the size and composition of the household according to the modified OECD scale (OECD 2020). ${ }^{14}$

In order to control graduates' differences in mobility, we included another instrument from the survey. Here, students were asked about their belief in the likelihood of being informed about vacant training positions by their social network (see Table 9). The answer is coded as a dummy variable that describes whether the individual has good access to training related information. One variable describes the distance individuals are willing to move from their current place of residence for vocational training (see Table 9). For the analysis, individuals willing to move throughout Germany and abroad are classified as mobile because they are not bound to a specific location. All others are considered to be immobile.

Gender and migration background related control variables are included as well. In accordance with a definition used by the Federal Statistical Office in Germany (Statistisches Bundesamt 2019a) that is frequently used in the literature (e.g., Lüdemann and Schwerdt 2013) individuals are ascribed a migration background in the analysis if at least one parent was not born in Germany. In order to control for the time between school graduation and start of a vocational training we included a time-lag variable that counts the years between graduating and entering the VET system.

\section{Results and discussion}

For the analysis of preference related questions (H1a-H1e), we estimate an MNL model with the sub-sample of students with ISS degree (Table 4). Here, interactions between preferences and type of region and interactions between preferences and Simpson index are included. For an analysis with respect to our ability and local labor market related questions (H2a-H2c and $\mathrm{H} 3$ ), we estimate a second MNL model for the whole sample, which includes students with LSS degree and ISS degree (Table 5). The model contains an interaction term between ability and the type of region and between ability and Simpson index. ${ }^{15}$

The estimated coefficients are represented as average marginal effects (AME) that express the direction and strength of the relationship between explanatory variables and individuals' likelihood of entering specific occupational segments. ${ }^{16}$ As the results are stated in terms of AMEs, coefficients of interacted variables in the main tables express

\footnotetext{
14 The first adult in the household is assigned a value of 1 , each additionally adult, i.e., a person of age 14 and older, a value of 0.5 and each person under 14 years a value of 0.3 (Hagenaars et al. 1994). The household income is divided by the equivalent household size (OECD 2015, 2020).

15 We only present the final interaction models but we estimated both models without regional variables and without interaction effects first. Overall, we obtained stable results across all three models. As further robustness check, we included the federal states as control variables for institutional differences in the full-and subsample model and obtained stable results with regard to our research questions. Additionally, we examined if the inclusion of parents 'occupations in our model alters our findings, which was not the case.

16 Marginal effects are calculated for each individual and covariate on the basis of all observed data. Afterwards, these calculated values are averaged across individuals.
} 


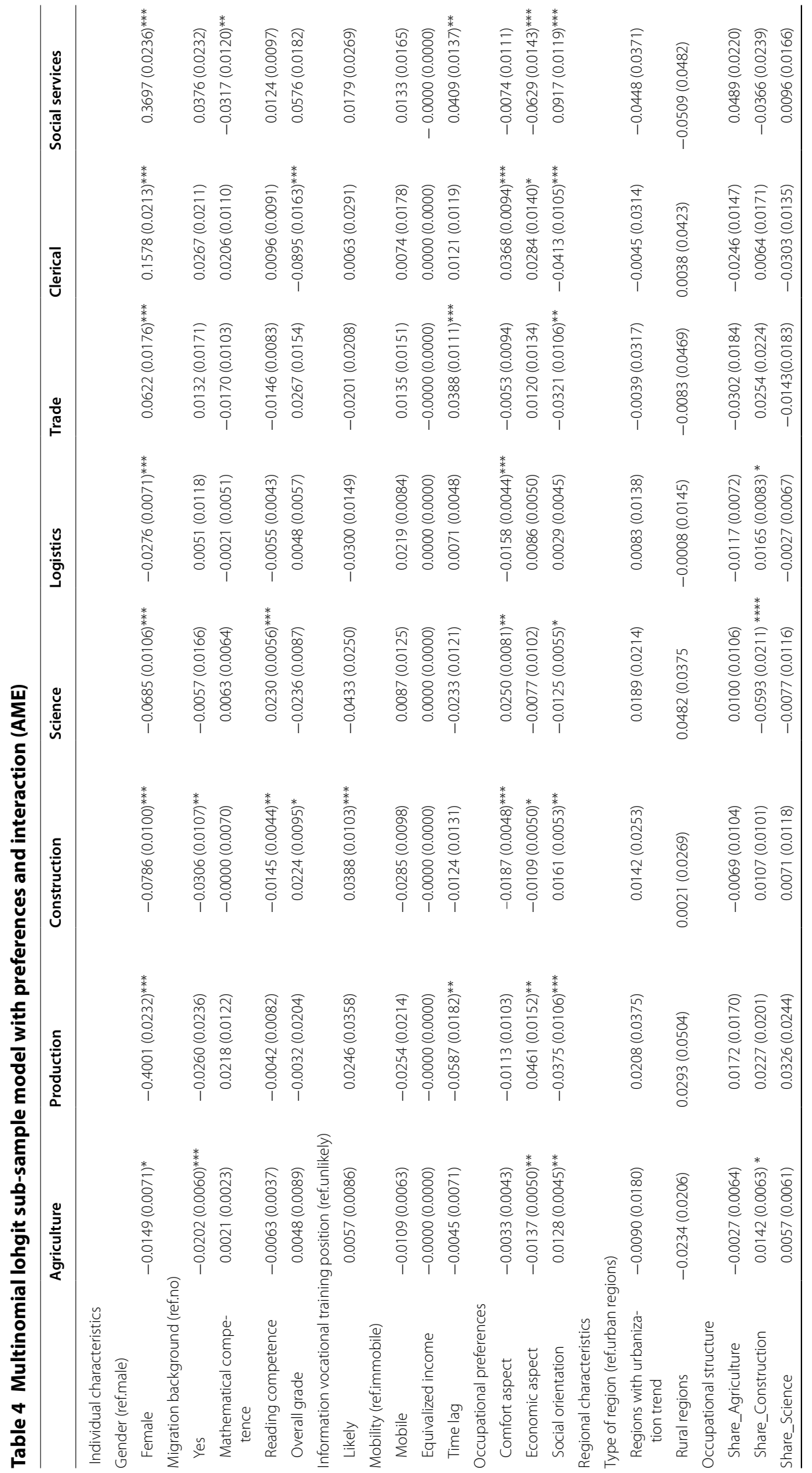




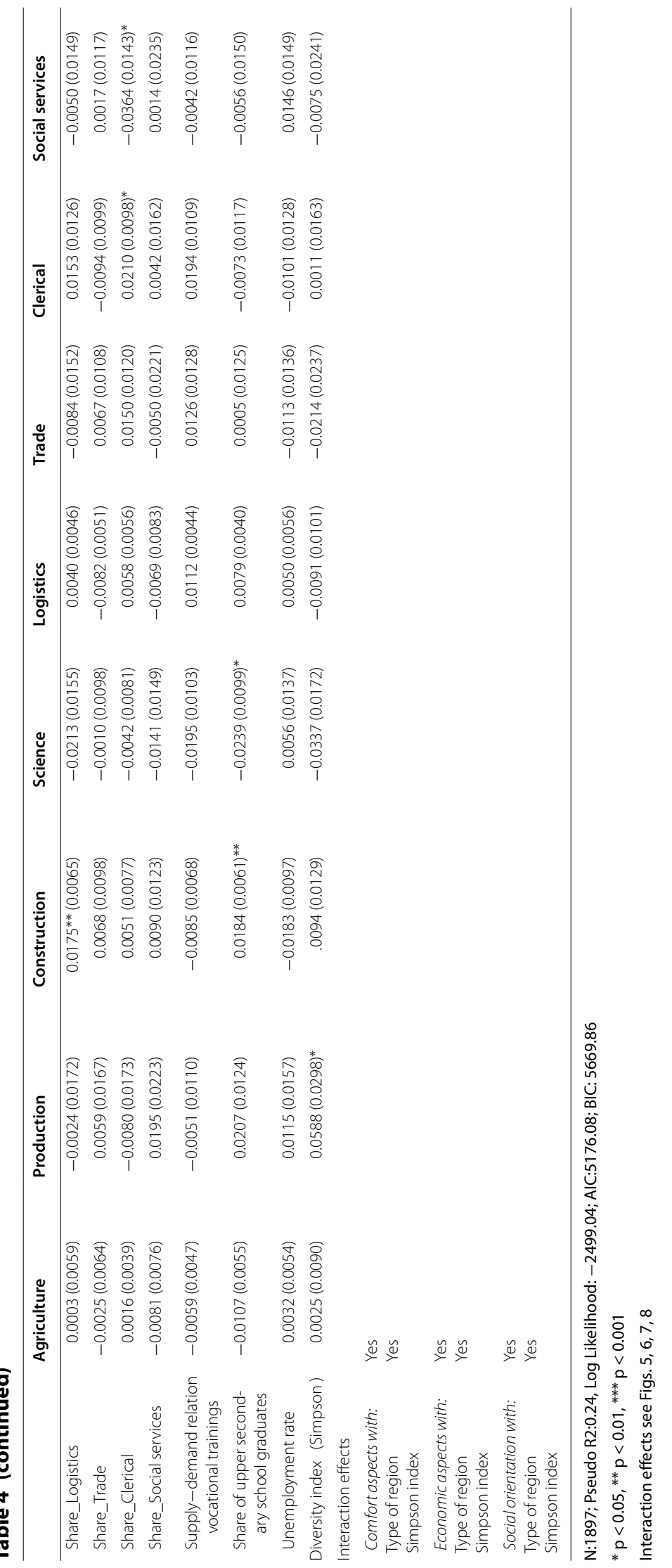


Table 5 Multinomial logit full-sample model without preferences (AME)

\begin{tabular}{|c|c|c|c|c|c|c|c|c|}
\hline & Agriculture & Production & Construction & Science & Logistics & Trade & Clerical & $\begin{array}{l}\text { Social } \\
\text { Services }\end{array}$ \\
\hline \multicolumn{9}{|c|}{ Individual characteristics } \\
\hline \multicolumn{9}{|c|}{ Gender (ref. male) } \\
\hline Female & $\begin{array}{l}-0.0127 \\
(0.0054) *\end{array}$ & $\begin{array}{l}-0.4141 \\
(0.0156) \\
* * *\end{array}$ & $\begin{array}{l}-0.1105 \\
(0.0088) \\
* * *\end{array}$ & $\begin{array}{l}-0.0490 \\
(0.0068) \\
* * *\end{array}$ & $\begin{array}{l}-0.0487 \\
(0.0064) \\
* * *\end{array}$ & $\begin{array}{l}0.0982 \\
(0.0123) \\
* * *\end{array}$ & $\begin{array}{l}0.1287 \\
(0.0136) \\
* * *\end{array}$ & $\begin{array}{l}0.4081 \\
(0.0151) \\
* * *\end{array}$ \\
\hline \multicolumn{9}{|c|}{ Migration background (ref.no) } \\
\hline Yes & $\begin{array}{c}-0.0209 \\
(0.0040)^{* * * *}\end{array}$ & $\begin{array}{l}-0.0190 \\
(0.0155)\end{array}$ & $\begin{array}{c}-0.0300 \\
(0.0110) * *\end{array}$ & $0.0040(0.0104)$ & $\begin{array}{l}-0.0022 \\
(0.0071)\end{array}$ & $\begin{array}{c}0.0256 \\
(0.0140)\end{array}$ & $\begin{array}{r}0.0328 \\
(0.0128)^{*}\end{array}$ & $\begin{array}{c}0.0097 \\
(0.0175)\end{array}$ \\
\hline $\begin{array}{l}\text { Mathematical } \\
\text { compe- } \\
\text { tence }\end{array}$ & $\begin{array}{l}0.0008 \\
(0.0021)\end{array}$ & $\begin{array}{c}0.0340 \\
(0.0088)^{* * *}\end{array}$ & $\begin{array}{l}-0.0085 \\
(0.0061)\end{array}$ & $\begin{array}{r}0.0097 \\
(0.0044)^{*}\end{array}$ & $\begin{array}{l}-0.0074 \\
(0.0039)\end{array}$ & $\begin{array}{r}-0.0141 \\
(0.0067) *\end{array}$ & $\begin{array}{c}0.0104 \\
(0.0077)\end{array}$ & $\begin{array}{c}-0.0249 \\
(0.0077)^{* *}\end{array}$ \\
\hline $\begin{array}{l}\text { Reading } \\
\text { compe- } \\
\text { tence }\end{array}$ & $\begin{array}{l}-0.0027 \\
(0.0030)\end{array}$ & $\begin{array}{l}-0.0064 \\
(0.0070)\end{array}$ & $\begin{array}{r}-0.0105 \\
(0.0049) *\end{array}$ & $\begin{array}{r}0.0105 \\
(0.0042) *\end{array}$ & $\begin{array}{l}-0.0042 \\
(0.0036)\end{array}$ & $\begin{array}{c}0.0052 \\
(0.0059)\end{array}$ & $\begin{array}{l}0.0029 \\
(0.0062)\end{array}$ & $\begin{array}{r}0.0156 \\
(0.0067)^{*}\end{array}$ \\
\hline $\begin{array}{l}\text { Overall } \\
\text { grade }\end{array}$ & $\begin{array}{c}0.0019 \\
(0.0056)\end{array}$ & $\begin{array}{l}-0.0055 \\
(0.0157)\end{array}$ & $\begin{array}{c}0.0273 \\
(0.0092) * *\end{array}$ & $\begin{array}{r}-0.0206 \\
(0.0076)^{* *}\end{array}$ & $\begin{array}{c}0.0044 \\
(0.0059)\end{array}$ & $\begin{array}{c}0.0382 \\
(0.0112)^{* * *}\end{array}$ & $\begin{array}{l}-0.0797 \\
(0.0108)\end{array}$ & $\begin{array}{r}0.0341 \\
(0.0107)^{* *}\end{array}$ \\
\hline \multicolumn{9}{|c|}{ School degree (ref. LSS degree) } \\
\hline ISS degree & $\begin{array}{c}0.0008 \\
(0.0060)\end{array}$ & $\begin{array}{r}-0.0362 \\
(0.0152) *\end{array}$ & $\begin{array}{c}-0.0557 \\
(0.0115)^{* * *}\end{array}$ & $\begin{array}{c}0.0401 \\
(0.0076)^{* * *}\end{array}$ & $\begin{array}{r}-0.0170 \\
(0.0074)^{*}\end{array}$ & $\begin{array}{l}-0.0046 \\
(0.0129)\end{array}$ & $\begin{array}{c}0.0998 \\
(0.0115)^{* * *}\end{array}$ & $\begin{array}{l}-0.0272 \\
(0.0166)\end{array}$ \\
\hline \multicolumn{9}{|c|}{ Information vocational training position (ref.unlikely) } \\
\hline Likely & $\begin{array}{c}0.0032 \\
(0.0051)\end{array}$ & $\begin{array}{l}-0.0211 \\
(0.0211)\end{array}$ & $\begin{array}{c}0.0254 \\
(0.0080) * *\end{array}$ & $\begin{array}{l}-0.0115 \\
(0.0123)\end{array}$ & $\begin{array}{r}-0.0088 \\
(0.0086)\end{array}$ & $\begin{array}{l}-0.0317 \\
(0.0178)\end{array}$ & $\begin{array}{l}-0.0008 \\
(0.0168)\end{array}$ & $\begin{array}{c}0.0453 \\
(0.0174)^{* *}\end{array}$ \\
\hline \multicolumn{9}{|c|}{ Mobility (ref.immobile) } \\
\hline Mobile & $\begin{array}{l}-0.0082 \\
(0.0043)\end{array}$ & $\begin{array}{l}-0.0078 \\
(0.0164)\end{array}$ & $\begin{array}{r}-0.0182 \\
(0.0084)^{*}\end{array}$ & $\begin{array}{l}-0.0002 \\
(0.0075)\end{array}$ & $\begin{array}{c}0.0129 \\
(0.0079)\end{array}$ & $\begin{array}{l}-0.0058 \\
(0.0120)\end{array}$ & $\begin{array}{l}-0.0010 \\
(0.0123)\end{array}$ & $\begin{array}{c}0.0282 \\
(0.0144)\end{array}$ \\
\hline $\begin{array}{l}\text { Equivalized } \\
\text { income }\end{array}$ & $\begin{array}{l}-0.0000 \\
(0.0000)\end{array}$ & $0.0000(0.0000)$ & $\begin{array}{l}-0.0000 \\
(0.0000)\end{array}$ & $0.0000(0.0000)$ & $\begin{array}{l}-0.0000 \\
(0.0000)\end{array}$ & $\begin{array}{l}-0.0000 \\
(0.0000)\end{array}$ & $\begin{array}{l}0.0000 \\
(0.0000)\end{array}$ & $\begin{array}{r}-0.0000 \\
(0.0000)^{*}\end{array}$ \\
\hline Time lag & $\begin{array}{l}-0.0076 \\
(0.0039)\end{array}$ & $\begin{array}{c}-0.0237 \\
(0.0099)^{*}\end{array}$ & $\begin{array}{r}-0.0228 \\
(0.0075)^{* *}\end{array}$ & $\begin{array}{l}-0.0073 \\
(0.0063)\end{array}$ & $\begin{array}{c}0.0113 \\
(0.0033)^{* * * *}\end{array}$ & $\begin{array}{r}0.0216 \\
(0.0068)^{* *}\end{array}$ & $\begin{array}{l}0.0101 \\
\quad(0.0068)\end{array}$ & $\begin{array}{c}0.0184 \\
(0.0086)^{*}\end{array}$ \\
\hline \multicolumn{9}{|c|}{ Regional characteristics } \\
\hline \multicolumn{9}{|c|}{ Type of region (ref.urban regions) } \\
\hline $\begin{array}{l}\text { Regions } \\
\text { with } \\
\text { urbani- } \\
\text { zation } \\
\text { trend }\end{array}$ & $\begin{array}{c}-0.0111 \\
(0.0131)\end{array}$ & $0.0205(0.0298)$ & $\begin{array}{l}-0.0024 \\
(0.0161)\end{array}$ & $0.0045(0.0133)$ & $\begin{array}{l}-0.0010 \\
(0.0134)\end{array}$ & $\begin{array}{l}-0.0447 \\
(0.0241)\end{array}$ & $\begin{array}{c}0.0119 \\
(0.0173)\end{array}$ & $\begin{array}{l}0.0222 \\
\quad(0.0221)\end{array}$ \\
\hline $\begin{array}{l}\text { Rural } \\
\text { regions }\end{array}$ & $\begin{array}{l}-0.0128 \\
(0.0179)\end{array}$ & $0.0436(0.0392)$ & $\begin{array}{l}-0.0183 \\
(0.0186)\end{array}$ & $0.0176(0.0190)$ & $\begin{array}{c}-0.0183 \\
(0.0152)\end{array}$ & $\begin{array}{l}-0.0702 \\
(0.0287)\end{array}$ & $\begin{array}{c}0.0421 \\
(0.0302)\end{array}$ & $\begin{array}{l}0.0162 \\
(0.0269)\end{array}$ \\
\hline \multicolumn{9}{|c|}{ Occupational structure } \\
\hline $\begin{array}{l}\text { Share_Agri- } \\
\text { culture }\end{array}$ & $\begin{array}{c}-0.0001 \\
(0.0051)\end{array}$ & $0.0112(0.0138)$ & $\begin{array}{l}0.0020 \\
(0.0091)\end{array}$ & $0.0028(0.0073)$ & $\begin{array}{l}-0.0039 \\
(0.0068)\end{array}$ & $\begin{array}{l}-0.0139 \\
(0.0120)\end{array}$ & $\begin{array}{l}-0.0210 \\
(0.0123)\end{array}$ & $\begin{array}{l}0.0230 \\
\quad(0.0167)\end{array}$ \\
\hline $\begin{array}{c}\text { Share_Con- } \\
\text { struction }\end{array}$ & $\begin{array}{c}0.0030 \\
(0.0070)\end{array}$ & $0.0094(0.0155)$ & $\begin{array}{c}0.0111 \\
(0.0080)\end{array}$ & $\begin{array}{l}-0.0252 \\
(0.0131)\end{array}$ & $\begin{array}{c}0.0119 \\
(0.0085)\end{array}$ & $\begin{array}{c}0.0321 \\
(0.0150)\end{array}$ & $\begin{array}{l}-0.0062 \\
(0.0153)\end{array}$ & $\begin{array}{c}-0.0360 \\
(0.0155) *\end{array}$ \\
\hline $\begin{array}{l}\text { Share_Sci- } \\
\text { ence }\end{array}$ & $\begin{array}{l}-0.0008 \\
(0.0048)\end{array}$ & $0.0095(0.0159)$ & $\begin{array}{l}0.0060 \\
(0.0068)\end{array}$ & $0.0010(0.0063)$ & $\begin{array}{l}-0.0113 \\
(0.0066)\end{array}$ & $\begin{array}{l}-0.0038 \\
(0.0113)\end{array}$ & $\begin{array}{l}-0.0044 \\
(0.0099)\end{array}$ & $\begin{array}{l}0.0037 \\
\quad(0.0125)\end{array}$ \\
\hline $\begin{array}{l}\text { Share__ } \\
\text { Logistics }\end{array}$ & $\begin{array}{l}-0.0006 \\
(0.0050)\end{array}$ & $\begin{array}{l}-0.0158 \\
(0.0117)\end{array}$ & $\begin{array}{c}0.0194 \\
(0.0043)^{* * *}\end{array}$ & $\begin{array}{l}-0.0102 \\
(0.0091)\end{array}$ & $\begin{array}{l}-0.0056 \\
(0.0055)\end{array}$ & $\begin{array}{l}-0.0021 \\
(0.0113)\end{array}$ & $\begin{array}{l}0.0190 \\
(0.0109)\end{array}$ & $\begin{array}{l}-0.0041 \\
(0.0113)\end{array}$ \\
\hline $\begin{array}{l}\text { Share_- } \\
\text { Trade }\end{array}$ & $\begin{array}{l}-0.0014 \\
(0.0047)\end{array}$ & $0.0049(0.0102)$ & $\begin{array}{l}0.0004 \\
(0.0060)\end{array}$ & 0.0009 (0.0056) & $\begin{array}{l}-0.0060 \\
(0.0047)\end{array}$ & $\begin{array}{l}0.0136 \\
(0.0075)\end{array}$ & $\begin{array}{c}0.0001 \\
(0.0078)\end{array}$ & $\begin{array}{r}-0.0125 \\
(0.0087)\end{array}$ \\
\hline $\begin{array}{l}\text { Share_Cleri- } \\
\text { cal }\end{array}$ & $\begin{array}{l}-0.0004 \\
(0.0037)\end{array}$ & $\begin{array}{c}-0.0277 \\
(0.0131) *\end{array}$ & $\begin{array}{c}0.0208 \\
(0.0055) * * *\end{array}$ & $\begin{array}{l}-0.0017 \\
(0.0044)\end{array}$ & $\begin{array}{l}0.0025 \\
(0.0046)\end{array}$ & $\begin{array}{c}0.0097 \\
(0.0074)\end{array}$ & $\begin{array}{c}0.0236 \\
(0.0068))^{* * *}\end{array}$ & $\begin{array}{l}-0.0267 \\
(0.0102) \\
* *\end{array}$ \\
\hline $\begin{array}{l}\text { Share_} \\
\text { Social } \\
\text { services }\end{array}$ & $\begin{array}{l}-0.0042 \\
(0.0075)\end{array}$ & $\begin{array}{l}-0.0095 \\
(0.0156)\end{array}$ & $\begin{array}{c}0.0113 \\
(0.0088)\end{array}$ & $\begin{array}{l}-0.0028 \\
(0.0088)\end{array}$ & $\begin{array}{c}-0.0145 \\
(0.0067)^{*}\end{array}$ & $\begin{array}{c}0.0106 \\
(0.0148)\end{array}$ & $\begin{array}{c}0.0152 \\
(0.0118)\end{array}$ & $\begin{array}{r}-0.0061 \\
(0.0164)\end{array}$ \\
\hline
\end{tabular}


Table 5 (continued)

\begin{tabular}{|c|c|c|c|c|c|c|c|c|}
\hline & Agriculture & Production & Constructior & Science & Logistics & Trade & Clerical & $\begin{array}{l}\text { Social } \\
\text { Services }\end{array}$ \\
\hline $\begin{array}{l}\text { Supply- } \\
\text { demand } \\
\text { relation } \\
\text { voca- } \\
\text { tional } \\
\text { trainings }\end{array}$ & $\begin{array}{l}-0.0052 \\
(0.0041)\end{array}$ & $\begin{array}{c}-0.0179 \\
(0.0084)^{*}\end{array}$ & $\begin{array}{l}-0.0077 \\
(0.0058)\end{array}$ & $\begin{array}{c}-0.0117 \\
(0.0058)^{*}\end{array}$ & $\begin{array}{l}0.0056 \\
(0.0041)\end{array}$ & $\begin{array}{c}0.0077 \\
(0.0084)\end{array}$ & $\begin{array}{c}0.0194 \\
(0.0087)^{*}\end{array}$ & $\begin{array}{l}0.0099 \\
(0.0088)\end{array}$ \\
\hline $\begin{array}{l}\text { Share of } \\
\text { upper } \\
\text { second- } \\
\text { ary } \\
\text { school } \\
\text { gradu- } \\
\text { ates }\end{array}$ & $\begin{array}{l}-0.0044 \\
(0.0035)\end{array}$ & $\begin{array}{c}0.0187 \\
(0.0083)^{*}\end{array}$ & $\begin{array}{c}0.0064 \\
(0.0074)\end{array}$ & $\begin{array}{c}-0.0131 \\
(0.0053)^{*}\end{array}$ & $\begin{array}{l}0.0024 \\
(0.0044)\end{array}$ & $\begin{array}{l}-0.0065 \\
(0.0084)\end{array}$ & $\begin{array}{l}-0.0122 \\
(0.0065)\end{array}$ & $\begin{array}{l}0.0086 \\
(0.0084)\end{array}$ \\
\hline $\begin{array}{l}\text { Unemploy- } \\
\text { ment } \\
\text { rate }\end{array}$ & $\begin{array}{l}-0.0044 \\
(0.0045)\end{array}$ & $0.0007(0.0114)$ & $\begin{array}{r}-0.0215 \\
(0.0069)^{* *}\end{array}$ & $0.0055(0.0088)$ & $\begin{array}{l}\quad 0.0038 \\
(0.0048)\end{array}$ & $\begin{array}{l}-0.0173 \\
(0.0104)\end{array}$ & $\begin{array}{c}0.0011 \\
(0.0089)\end{array}$ & $\begin{array}{l}0.0320 \\
(0.0097)\end{array}$ \\
\hline $\begin{array}{c}\text { Simpson } \\
\text { index }\end{array}$ & $\begin{array}{l}-0.0032 \\
(0.0086)\end{array}$ & $0.0269(0.0232)$ & $\begin{array}{c}0.0133 \\
(0.0098)\end{array}$ & $\begin{array}{l}-0.0169 \\
(0.0092)\end{array}$ & $\begin{array}{l}-0.0162 \\
(0.0089)\end{array}$ & $\begin{array}{l}0.0072 \\
(0.0149)\end{array}$ & $\begin{array}{l}0.0163 \\
(0.0109)\end{array}$ & $\begin{array}{r}-0.0273 \\
(0.0165)\end{array}$ \\
\hline \multicolumn{9}{|c|}{ Interaction effect } \\
\hline \multicolumn{9}{|l|}{$\begin{array}{l}\text { School degree } \\
\text { with: }\end{array}$} \\
\hline
\end{tabular}

N: 3403; Pseudo R2: 0.22; Log Likelihood: -4706.99; AIC: 9593.97; BIC: 10,145.89

${ }^{*} \mathrm{p}<0.05,{ }^{* *} \mathrm{p}<0.01,{ }^{* * *} \mathrm{p}<0.001$

Interaction effects see Figs. 9, 10

gross effects that summarize main and interaction effects and express mean effects across all observations. Results for partial analyses of interactions that hold one effect constant while the other varies are presented in separate figures.

\section{Realization of preferences (H1a-H1e)}

According to the results from the sub-sample model without LSS graduates (Table 4), ISS graduates with high valuation of comfort aspects have, as expected, generally an increased propensity for entering the training segments of clerical and science-related occupations but avoid specifically production, construction or logistics-related occupations. More concretely, if ISS graduate's comfort preferences are higher by one point, their likelihood of entering VET in a clerical occupation is 3.86 percentage points higher than that of ISS graduates with the lower comfort preference. ISS graduates with high valuation of economic aspects have a strongly increased propensity for entering production-related and, secondly, clerical occupations, but a specifically strongly reduced propensity for training in the social segment. Graduates with a strong social orientation, finally, have a still stronger propensity for entering the social segment as expected by H1c. They also have a distinctively reduced propensity for entering production, trade or clerical occupations. The effects of interactions between preferences and type of region are illustrated in Fig. 5.

In perfect alignment with H1a, ISS graduates with strong economic preferences have an increased propensity for production-related occupations in urban labor markets (see Fig. 5). In rural locations, ISS graduates with strong economic preferences have only a weakly inclined propensity for science related and specifically for clerical occupations, 


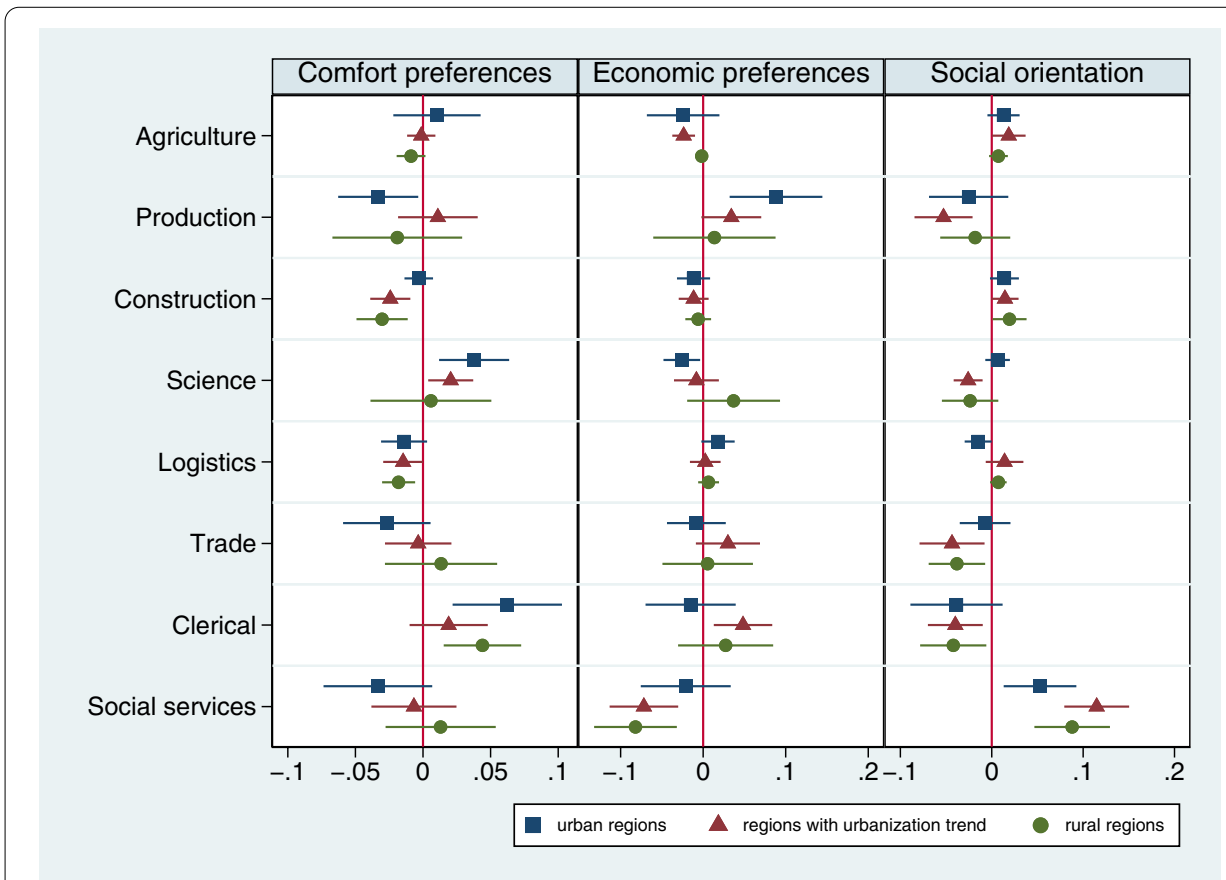

Fig. 5 Effects of economic, comfort and social orientation by the type of region (interaction effects). Data source: NEPS, SC4, estimation see Table 4

which are rather avoided by their urban counterparts. Generally, and in line with the opportunity structure argument, the likelihood of realization of economic preferences seems to be highest in urban locations with well-paid production occupations.

The interaction of economic preferences with the diversity index further illuminates the relationship (Fig. 6). Where production is concentrated and diversity is consequently low, graduates with strong economic preferences have an increased propensity for entering production. In other words: The higher the concentration of production at a location is, the higher the economic advantages it promises for VET entrants. Only in locations with high diversity and a distinctively low share of production, do clerical, and to a lesser extent also trade and science occupations apparently provide the better options for the realization of ISS graduates' economic preferences.

In partial support of H1e, the observed graduates have a higher likelihood of realizing economic preferences within the clerical or even the science segment in rural than in urban regions, which supports the competition argument. H1e is not confirmed, however, with respect to comfort preferences. They are obviously best served by entering clerical occupations in urban and rural regions alike. The observation that graduates in urban locations have a higher likelihood of meeting their comfort preferences in science occupations than in rural locations supports $\mathrm{H} 1 \mathrm{~b}$ and the opportunity structure argument.

This relevance of diversity is further supported by the interaction between comfort preferences and the diversity index (Fig. 7): While positions in the science and clerical segments seem to provide the best options for comfort-inclined graduates everywhere, more graduates can realize this promise in locations with higher diversity (lower index value). Contrary to H1d, higher diversity does not imply a larger spread of segments of 


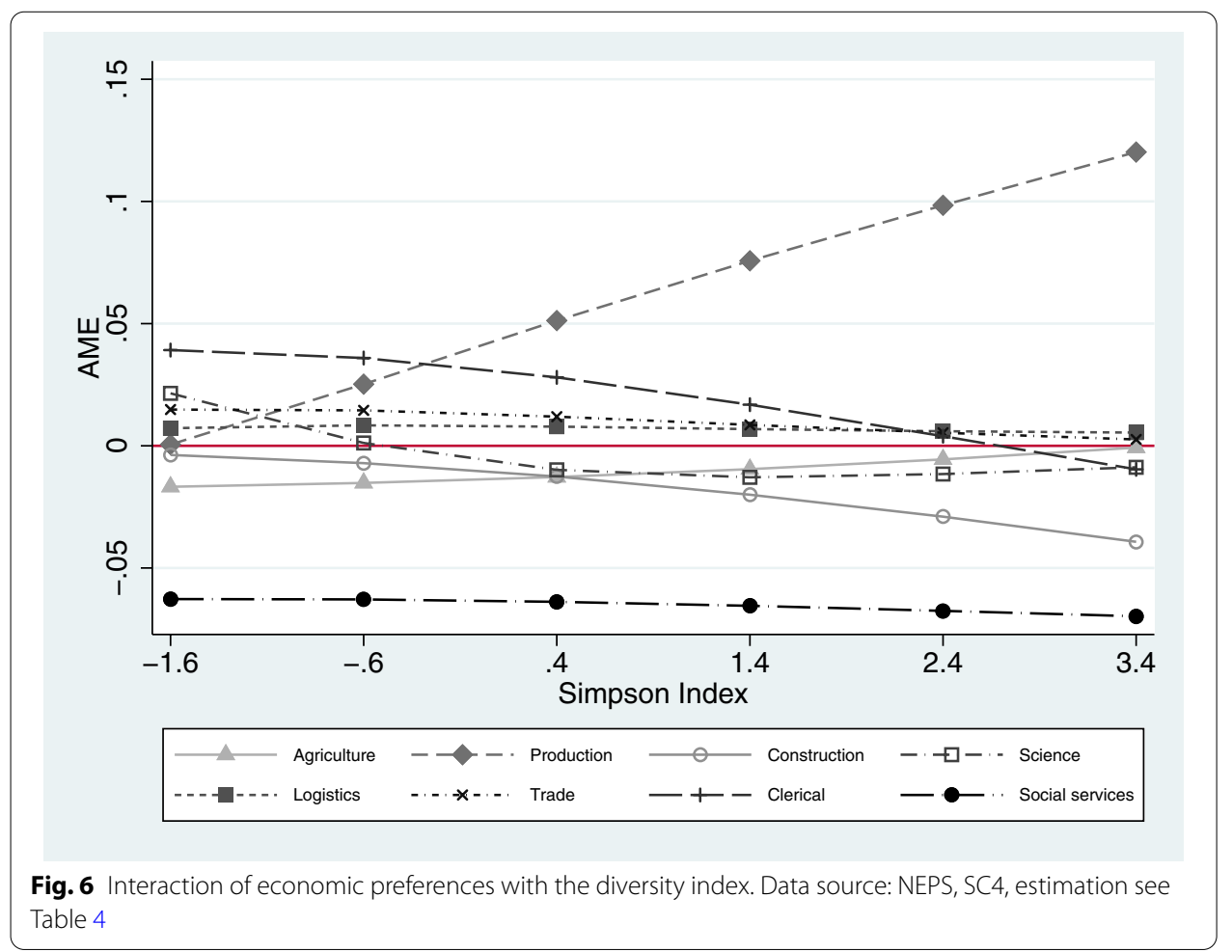

interest for comfort-inclined graduates as there seem to be few true alternatives within other segments.

Finally, and as expected by H1c, a strong social orientation generally increases graduates' likelihood for entering the social segment (see Fig. 5). This effect is slightly stronger in non-urban than in urban region. This stronger focus on the social segment does not seem to be due to higher diversity in urban locations as expected by H1d, however: What we observe for urban regions is no increased selection of graduates with social orientation into more occupation segments but instead a stronger avoidance of certain segments like trade or science.

It is illuminating then that the opportunity for the realization of a strong social orientation is also a little better in more diverse labor markets (Fig. 8). In locations with low diversity, where the effect of social orientation on the likelihood of entering the social segment is not much higher than on the likelihood of entering the construction segment, the main adaption to a social orientation seems to be avoidance of the production segment. The relevant diversity seems to be well-captured by our index here and diversity, once again, seems to be a dominant argument with respect to ISS graduates' ability to realize their preferences with their VET entry field.

\section{Selection on ability $(\mathrm{H} 2 \mathrm{a}-\mathrm{H} 2 \mathrm{c})$}

According to the full-sample model (Table 5) the ISS degree as expected considerably increases graduates' likelihood of entering VET in the science and specifically the clerical segment if compared to the LSS degree. Based on the full-sample model (see Table 5), the interaction effects allow us to analyze the extent to which the relationship 


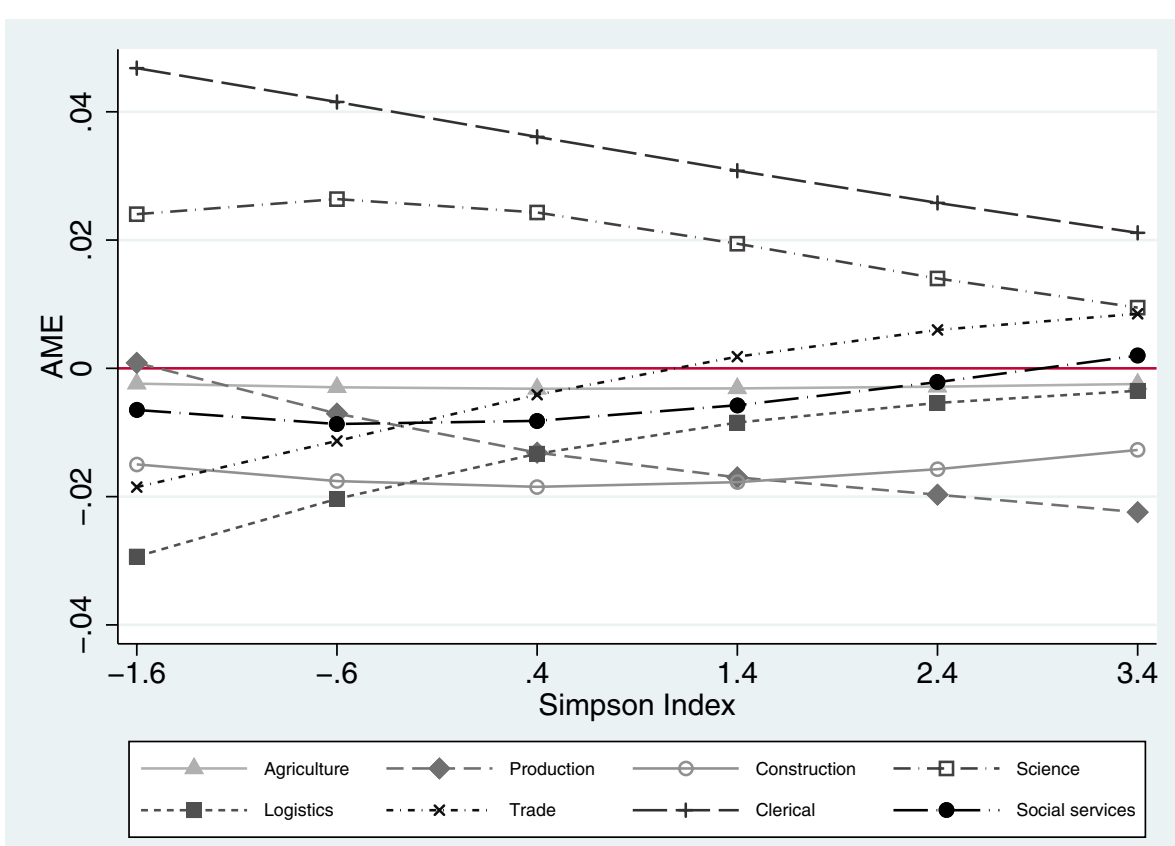

Fig. 7 Interaction of comfort preferences with the diversity index. Data source: NEPS, SC4, estimation see Table 4

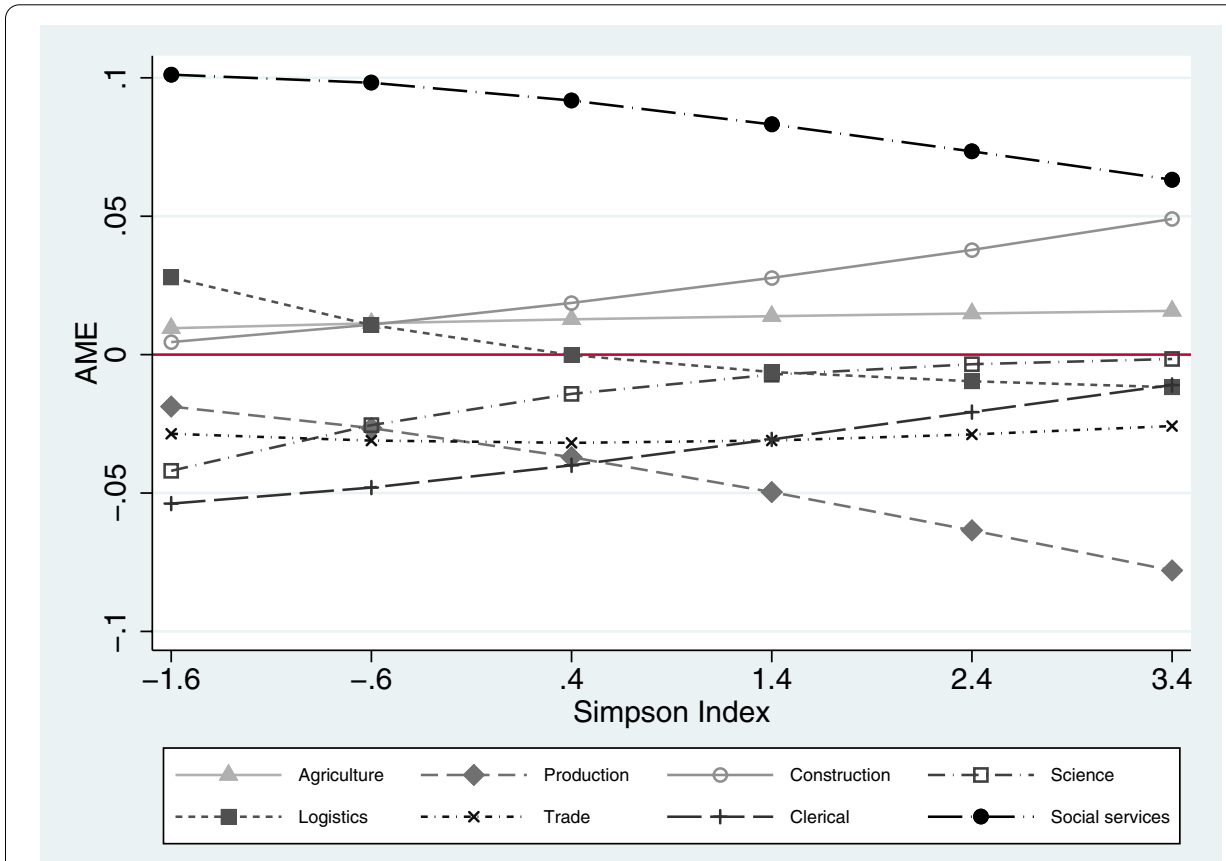

Fig. 8 Interaction of social orientation with the diversity index. Data source: NEPS, SC4, estimation see Table 4 


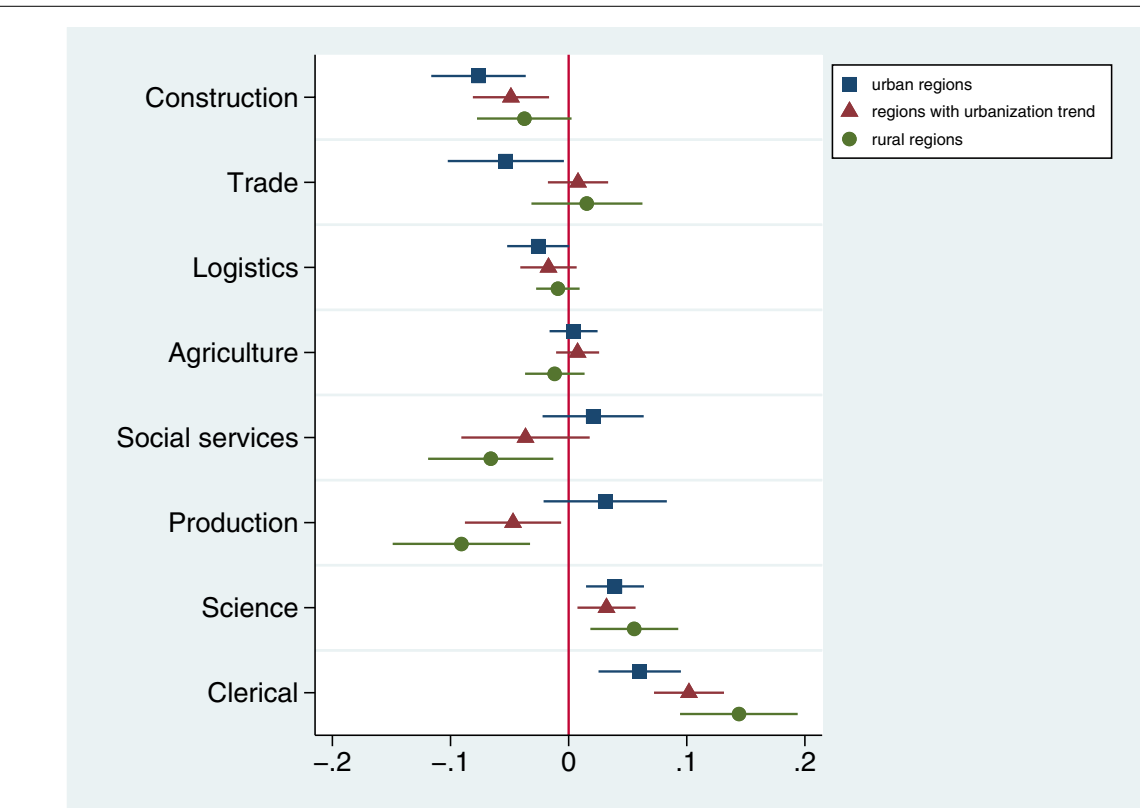

Fig. 9 Interaction of secondary school degree with type of region. Data source: NEPS, SC4, estimation see Table 5

between ability as determined by school degree and VET entry segment differ by the type of region (Fig. 9). ISS as compared to LSS graduates' likelihood of entering VET in the clerical and science segments is specifically increased in rural labor markets, as expected by H2a. In urban labor markets, in contrast, where the competition with USS graduates is specifically strong in the clerical and science segment, ISS graduates, in line with $\mathrm{H} 2 \mathrm{~b}$, seem to enter preferably production.

The interaction of school degree with the diversity index (Fig. 10) clearly supports the idea that the concentration of graduates with higher ability on the clerical segment is stronger in more homogenous locations with fewer alternatives (H2c). Occupations in science and trade seem to provide alternatives to the clerical segment for ISS graduates in more diverse labor markets.

\section{Local occupational structure (H3)}

The sub-sample model in Table 4 and the full-sample model in Table 5 confirm that the regional occupation structure relates to graduates' VET choices as expected under conditions of information and mobility restrictions. A distinctively positive relationship between an occupation's share in the workforce and graduates' likelihood for entering VET in the same segment is observed, when the positive relationship to the same segment is stronger than that to any other segment. We find this situation for the clerical segment as expected by $\mathrm{H} 3$.

With respect to production and the science segment, however, the effect of the local occupation structure is captured by the diversity index instead. In regions with high Simpson index values, respectively low diversity, graduates' likelihood for entering VET in the production segment is significantly increased, specifically in the sub-sample 


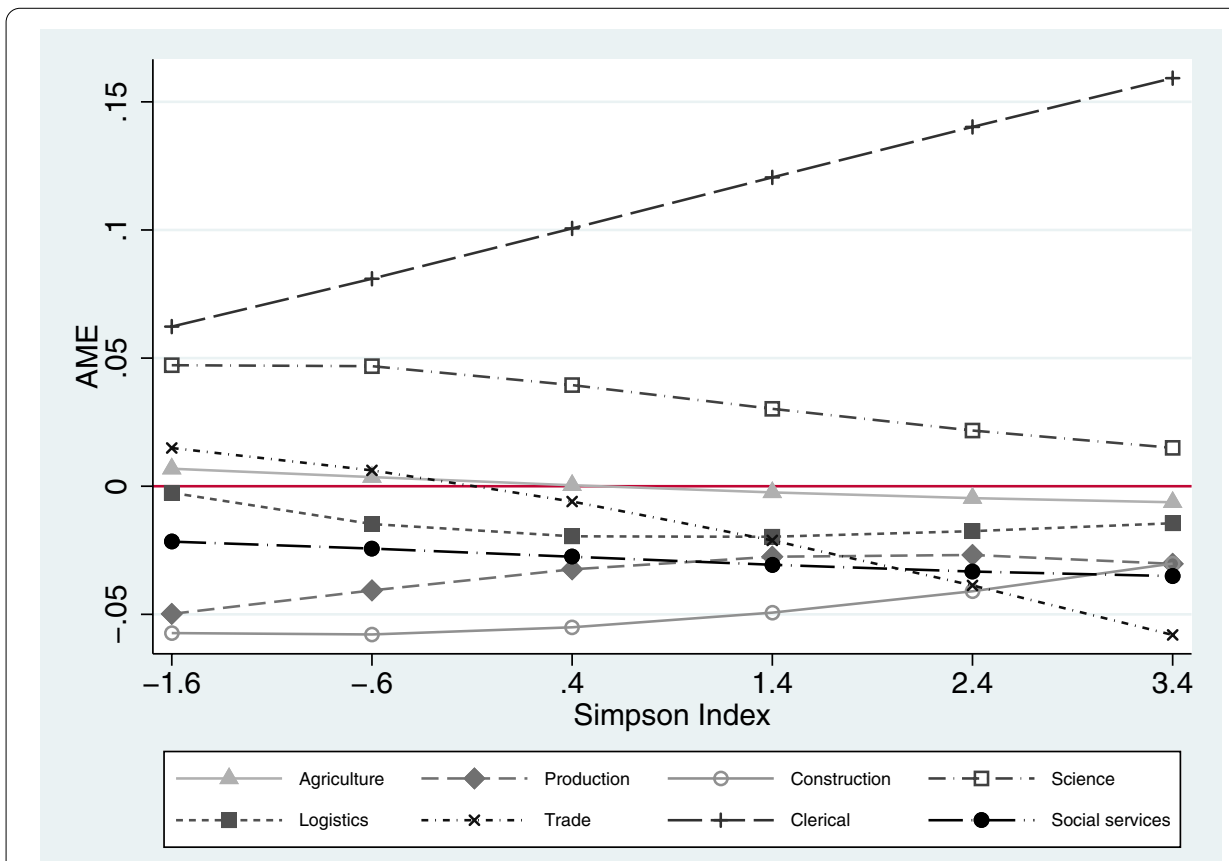

Fig. 10 Interaction of diversity index with ISS in reference to LSS degree. Data source: NEPS, SC4, estimation see Table 5

model for ISS graduates (see Table 4). This result supports $\mathrm{H} 3$ as production is the largest occupation segment and usually specifically strong in labor markets with reduced diversity. Similarly, and again in line with $\mathrm{H} 3$, in regions with high labor market diversity (low index value), where science tends to have relatively high shares, graduates' propensity for entering the science segment is higher than with low diversity (see Tables 4 and 5). The Simpson index together with occupational shares consequently reflects, albeit imperfectly, the occupational or opportunity structure that is relevant for LSS and ISS graduates.

\section{Conclusion}

This paper has analyzed how local labor market conditions affect ISS and LSS graduates' likelihood of entering VET in different occupational segments conditional on abilities and specific preferences. The hypotheses that have guided the analysis focus on the relationship between competition/labor market density, opportunity structure / labor market diversity, and relative attractiveness of different VET entry segments at given preferences or abilities. The hypotheses were derived from the literature and further substantiated by additional information on VET entry segments and their regional distribution.

The results have confirmed that regional differences in VET entry can generally be explained in terms of opportunity structure on the one hand and VET market competition on the other hand. The partial antagonism between both explains urban labor markets' ambiguous effect on preference realization. The competition argument is specifically important in order to explain the stronger selection on ability in urban 
labor markets. Due to the reduced competition and selection on ability in rural labor markets, ISS graduates' opportunities for the realization of attractive VET choices are not generally worse in rural than in urban labor markets despite the latter's better opportunity structure. Instead, ISS as compared to LSS graduates have specifically good opportunities for entering VET in the attractive clerical segment in rural regions, where competition by USS graduates is low.

Reduced labor market diversity as it is typical for rural locations, however, comes along with reduced opportunities for the realization of specific preferences for ISS graduates. While comfort preferences seem to generally be better realizable in diverse urban labor markets, the realization of economic preferences depends largely on the local concentration of attractive production occupations. They are, however, more often concentrated in urban and peri-urban than in rural locations. Social orientation, in contrast, can best be realized by ISS graduates in rural and specifically in peri-urban locations, while the social segment's attractiveness additionally relates positively to labor market diversity as well.

In summary, rural locations suffer from a reduced selection on ability due to their lower attractiveness for USS graduates; but they benefit from young graduates' adaption to the local opportunity structure. This applies specifically to the successful small and medium manufacturing enterprises with few academically trained employees that are characteristic for German rural regions with low in-migration and that exploit the advantages of stable employment relationships (Lehmann et al. 2019). Nevertheless, while short-term effects of mobility restrictions on the local industry development might be positive, medium and long-term effects on the individual and general economic welfare can be detrimental and remain ambiguous at best.

While the implications for policy therefore depend on the importance attached to different welfare effects, improving access to information and mobility and designing policies that take dynamic effects into account should in principle contribute to increasing welfare. If, for example, clerical occupations attract relatively low-skilled trainees at the expense of social services in thin rural labor markets, all parties might be better off if clerical occupations in rural regions started to increase their economic and non-economic benefits compared to clerical occupations in urban regions in order to motivate in-migration of higher skilled individuals and if, at the same time, rural trainees' mobility would be supported in order to increase their feasible range of opportunities.

Our paper has some limitation. The analysis is descriptive in character: The reduced form model does not mirror the exact decision-making problem and cannot claim to identify causal relationships. Formulation of a structural model that better describes direct as well as indirect relationships, for example with explicit consideration of different decision-making steps or of the mediating character of family background remains a challenge due to the categorical character of the outcome variable. Another potential extension would be the inclusion not only of decision-maker but also of choice characteristics within the regression model. Furthermore, there are over 300 different vocational trainings in Germany and we could only look at eight broad occupational categories. A more differentiated analysis that makes better allowance for the diversity of vocational trainings would be of high value but would require new methodological 
approaches. Our results provide first insights into the complex relationship between characteristics of individuals and regions on the one hand and VET choices on the other hand. They prepare the ground for further research on the precise mechanisms that determine how the socioeconomic environment and occupational structure shape individuals' preferences and their VET choices. If these mechanisms are known, it will be easier to identify effective measures against mismatches on the VET market.

Abbreviations

AME: Average marginal effects; BA: Federal Employment Agency; BBSR: Federal Institute for Research for Building, Urban Affairs and Spatial Development; BMBF: German Federal Ministry of Education and Research; ISS: Intermediate secondary school; KldB 2010: German Classification of Occupations, edition 2010; LIfBi: Leibniz Institute for Educational Trajectories; LSS: Lower secondary school; MNL: Multinomial logit; NEPS: National Educational Panel Study; SC4: Starting cohort four; USS: Upper secondary school; VET:Vocational education and training.

\section{Acknowledgements}

We would like to thank Guido Heineck and Christian Hundt for their comments on our manuscript.

Authors' contributions

All authors read and approved the final manuscript.

Funding

This research received no specific grant from any funding agency in the public, commercial, or not-for-profit sectors.

\section{Availability of data and materials}

The data that support the findings of this study are available from the Leibniz Institute for Educational Trajectories (LIfBi) but restrictions apply to the availability of these data, which were used under license for the current study, and so are not publicly available. This paper uses data from the National Educational Panel Study (NEPS): Starting Cohort Grade 9, https://doi.org/10.5157/NEPS:SC4:10.0.0.

Competing interests

The authors declare that they have no competing interests.

\section{Appendix}

See Tables 6, 7, 8, 9, 10, 11, 12.

\section{Section A4.1: description of the occupations' quality dimension}

For the description of occupations' quality dimensions, mean indicator values across all occupational groups and for each occupational group were calculated. Occupational groups are then described by their deviation from the grand mean. The labels "average" and "sometimes" describe quality dimension which correspond to the mean values across all occupational categories. A downward deviation from the mean is indicated

Table 6 KIdB 2010, one-digit

\begin{tabular}{lll}
\hline Category & KIdB 2010 & Description \\
\hline Agriculture & 1 & Occupations in agriculture, forestry, fishery and gardening \\
Production & 2 & Occupations in production of raw material, processing and manufacturing \\
Construction & 3 & Occupations in construction and related activities \\
Science & 4 & Occupations in science, geography and informatics \\
Logistics & 5 & Occupations in logistics, transportation and security \\
Trade & 6 & Occupations in trade and tourism \\
Clerical & 7 & Occupations in company organization, accounting, administration and law \\
Social services & 8 & Occupations in human health and social activities, education \\
Cultural Services & 9 & Occupations in linguistic, literature, social science, economics, media rela- \\
& & tions, cultural and art services
\end{tabular}

Data source: Bundesagentur für Arbeit (2011) 
Table 7 Descriptive statistics of independent categorical variables for each occupational category in \%

\begin{tabular}{|c|c|c|c|c|c|c|c|c|c|}
\hline & Agriculture & Production & Construction & Science & Logistics & Trade & Clerical & $\begin{array}{l}\text { Social } \\
\text { services }\end{array}$ & Total \\
\hline \multicolumn{10}{|c|}{ Fullsample ( $\mathrm{N}=3403)$} \\
\hline \multicolumn{10}{|c|}{ Individual characteristics } \\
\hline \multicolumn{10}{|l|}{ Gender } \\
\hline Female & 27.14 & 11.17 & 4.15 & 15.92 & 14.29 & 63.57 & 72.10 & 87.21 & 43.76 \\
\hline \multicolumn{10}{|c|}{ Migration background } \\
\hline Yes & 5.71 & 20.67 & 19.09 & 19.11 & 26.32 & 32.02 & 24.94 & 25.69 & 23.57 \\
\hline \multicolumn{10}{|l|}{ School degree } \\
\hline $\begin{array}{l}\text { Interme- } \\
\text { diate } \\
\text { sec- } \\
\text { ondary } \\
\text { school } \\
\text { degree }\end{array}$ & 72.86 & 68.43 & 47.30 & 92.36 & 50.38 & 64.50 & 91.11 & 71.41 & 70.35 \\
\hline \multicolumn{10}{|c|}{ Information vocational training position } \\
\hline Likely & 85.71 & 80.30 & 83.82 & 84.08 & 74.44 & 79.81 & 88.89 & 87.82 & 83.40 \\
\hline \multicolumn{10}{|l|}{ Mobility } \\
\hline Mobile & 20.00 & 27.44 & 20.75 & 29.30 & 33.83 & 27.15 & 29.88 & 32.93 & 28.74 \\
\hline \multicolumn{10}{|c|}{ Regional characteristics } \\
\hline \multicolumn{10}{|c|}{ Type of region } \\
\hline $\begin{array}{l}\text { Urban } \\
\text { regions }\end{array}$ & 30.00 & 25.07 & 37.76 & 35.67 & 29.32 & 32.25 & 25.43 & 29.79 & 28.83 \\
\hline $\begin{array}{l}\text { Regions } \\
\text { with } \\
\text { urbani- } \\
\text { zation } \\
\text { trend }\end{array}$ & 42.86 & 48.02 & 44.81 & 40.13 & 47.37 & 43.85 & 41.48 & 44.75 & 45.20 \\
\hline $\begin{array}{l}\text { Rural } \\
\text { regions }\end{array}$ & 27.14 & 26.91 & 17.43 & 24.20 & 23.31 & 23.90 & 33.09 & 25.45 & 25.98 \\
\hline \multicolumn{10}{|c|}{ Subsamle ( $N=1897)$} \\
\hline \multicolumn{10}{|c|}{ Individual characteristics } \\
\hline \multicolumn{10}{|l|}{ Gender } \\
\hline Female & 30.23 & 13.43 & 4.40 & 16.52 & 16.33 & 61.61 & 70.31 & 88.47 & 46.65 \\
\hline \multicolumn{10}{|c|}{ Migration background } \\
\hline Yes & 4.65 & 16.18 & 8.79 & 14.78 & 20.41 & 24.64 & 19.80 & 21.38 & 18.40 \\
\hline \multicolumn{10}{|c|}{ Information vocational training position } \\
\hline Likely & 90.70 & 88.35 & 95.60 & 84.35 & 73.47 & 87.20 & 92.15 & 91.40 & 89.35 \\
\hline \multicolumn{10}{|l|}{ Mobility } \\
\hline Mobile & 20.93 & 28.16 & 18.68 & 31.30 & $53 . .06$ & 33.65 & 31.06 & 33.54 & 30.79 \\
\hline \multicolumn{10}{|c|}{ Regional characteristics } \\
\hline \multicolumn{10}{|l|}{ Type of region } \\
\hline $\begin{array}{l}\text { Urban } \\
\text { regions }\end{array}$ & 27.91 & 25.73 & 30.77 & 32.17 & 26.53 & 30.33 & 21.84 & 28.72 & 27.10 \\
\hline $\begin{array}{l}\text { Regions } \\
\text { with } \\
\text { urbani- } \\
\text { zation } \\
\text { trend }\end{array}$ & 41.86 & 45.79 & 47.25 & 43.48 & 40.82 & 40.76 & 42.66 & 43.40 & 43.86 \\
\hline $\begin{array}{l}\text { Rural } \\
\text { regions }\end{array}$ & 30.23 & 28.48 & 21.98 & 24.35 & 32.65 & 28.91 & 35.49 & 27.88 & 29.05 \\
\hline
\end{tabular}

Data source: NEPS, SC4 


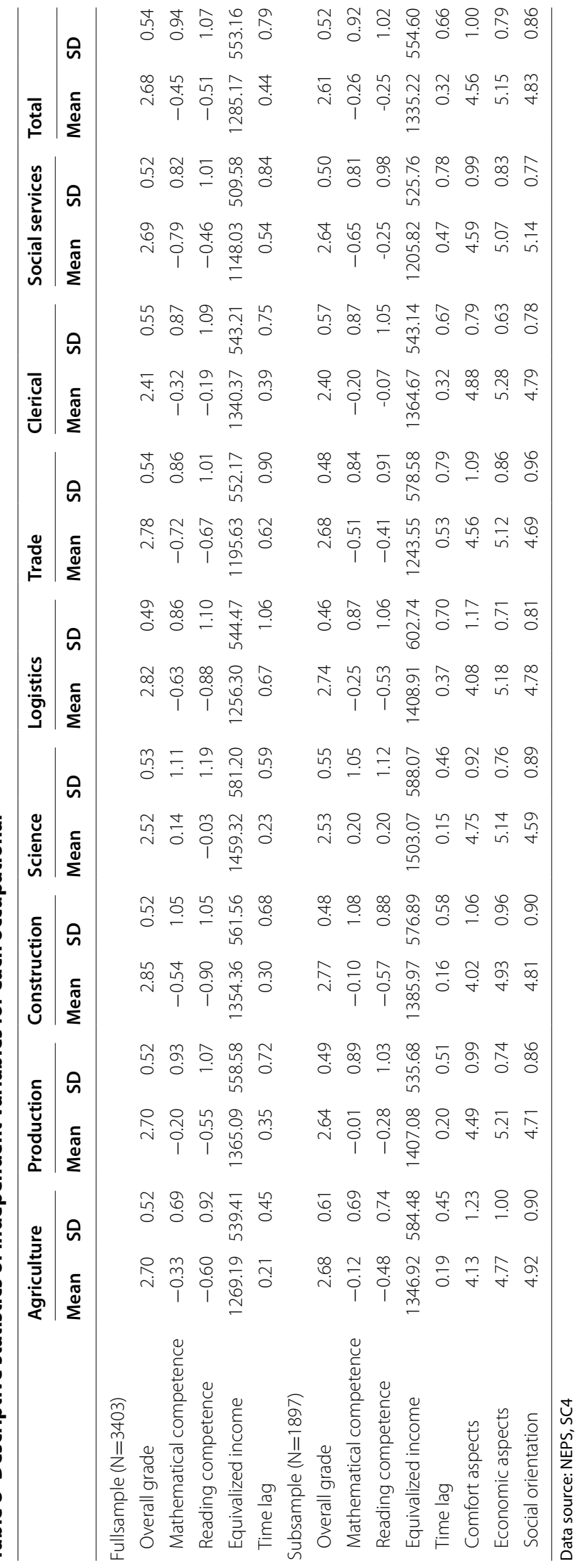


Table 9 Variables in the NEPS data and their description

\begin{tabular}{|c|c|c|}
\hline Variable & Question & Description \\
\hline Vocational training & $\begin{array}{l}\text { In which job have you been doing this vocational train- } \\
\text { ing /are you doing this vocational training right now? } \\
\text { Please specify the exact name for instance how it is } \\
\text { stated in your training contract }\end{array}$ & $\begin{array}{l}1 \text { Agriculture } \\
2 \text { Production } \\
3 \text { Construction } \\
4 \text { Science } \\
5 \text { Logistics } \\
6 \text { Trade } \\
7 \text { Clerical } \\
8 \text { Social services }\end{array}$ \\
\hline Gender & Are you... male?...female? & $\begin{array}{l}0 \text { Male } \\
1 \text { Female }\end{array}$ \\
\hline Migration background & $\begin{array}{l}\text { In what country was your mother born? In what country } \\
\text { was your father born? }\end{array}$ & $\begin{array}{l}0 \text { Germany } \\
1 \text { Not Germany }\end{array}$ \\
\hline School degree & Which school-leaving certificate did you obtain? & $\begin{array}{l}0 \text { Lower secondary schoo } \\
\text { degree } \\
1 \text { Intermediate secondary } \\
\text { school degree }\end{array}$ \\
\hline Overall grade & $\begin{array}{l}\text { What was the approximate overall grade on your gradu- } \\
\text { ation certificate for this school-leaving certificate? }\end{array}$ & School grades from 1 to 6 \\
\hline Mobility & $\begin{array}{l}\text { Would you move to another town for an apprentice- } \\
\text { ship? } \\
\text { (1) No; (2) Yes, but only in the near vicinity; (3) Yes, } \\
\text { throughout Germany; } \\
\text { (4) Yes, also abroad }\end{array}$ & $\begin{array}{l}0 \text { Immobile }(1,2) \\
1 \text { Mobile }(3,4)\end{array}$ \\
\hline $\begin{array}{l}\text { Information vocational } \\
\text { training position }\end{array}$ & $\begin{array}{l}\text { The following questions are about the people in your } \\
\text { life, whether you know them well or not. Imagine you } \\
\text { are looking for a vocational training position. How } \\
\text { likely is it that people in your life would let you know } \\
\text { about interesting open vocational training positions? }\end{array}$ & $\begin{array}{l}0 \text { Unlikely } \\
1 \text { Likely }\end{array}$ \\
\hline Household income & $\begin{array}{l}\text { (1)What is your monthly household income? Please give } \\
\text { the net amount, after deduction of all taxed and social } \\
\text { security contributions. Please include regular pay- } \\
\text { ments received such as pensions, housing assistance, } \\
\text { parental and children benefits, BAFöG, support pay- } \\
\text { ments, unemployment etc } \\
\text { (2) Does your monthly household income amount to } \\
\text { less than EUR 1,500., EUR 1,500 to 3000, or more than } \\
\text { EUR 3,000? }\end{array}$ & $\begin{array}{l}1 \text { Less than } 1,500 € \\
21,500 \text { to } 3,000 € \\
3 \text { More than } 3,000 €\end{array}$ \\
\hline Household size & $\begin{array}{l}\text { How many persons normally live in your home-yourself } \\
\text { included? }\end{array}$ & $\geq 1$ \\
\hline $\begin{array}{l}\text { Persons under } 14 \text { in the } \\
\text { household }\end{array}$ & How many of these people are under 14 years of age? & $\geq 0$ \\
\hline \multicolumn{3}{|l|}{ Occupational Preferences } \\
\hline $\begin{array}{l}\text { Comfort and economic } \\
\text { aspects, social orienta- } \\
\text { tion }\end{array}$ & $\begin{array}{l}\text { Below we have listed some things that could be } \\
\text { important aspects of a job or trade. How important } \\
\text { are these things for your personally, regardless of your } \\
\text { current situation? Please answer on a scale from } 1 \text { to } \\
6 . \text { ' } 1 \text { ' means that this aspect is very unimportant to } \\
\text { you. '6' means that it is very important to you. You can } \\
\text { use the number in between to indicate the degree of } \\
\text { importance. How important is it to you....? }\end{array}$ & \\
\hline Comfort aspects & $\begin{array}{l}\text { Items: (1) pleasant working hours, (2) good work envi- } \\
\text { ronment (such as lighting, temperature, cleanliness, } \\
\text { low noise levels) }\end{array}$ & Overall score from 0 to 6 \\
\hline Economic aspects & $\begin{array}{l}\text { Items: (1): good chances to advance professionally, (2) } \\
\text { high job security, (3) good pay }\end{array}$ & Overall score from 0 to 6 \\
\hline Social orientation & $\begin{array}{l}\text { Items: (1) work that of use to society, (2) opportunity } \\
\text { to help others, (3) the feeling of doing something } \\
\text { meaningful }\end{array}$ & Overall score from 0 to 6 \\
\hline
\end{tabular}

Data source: NEPS, SC4 


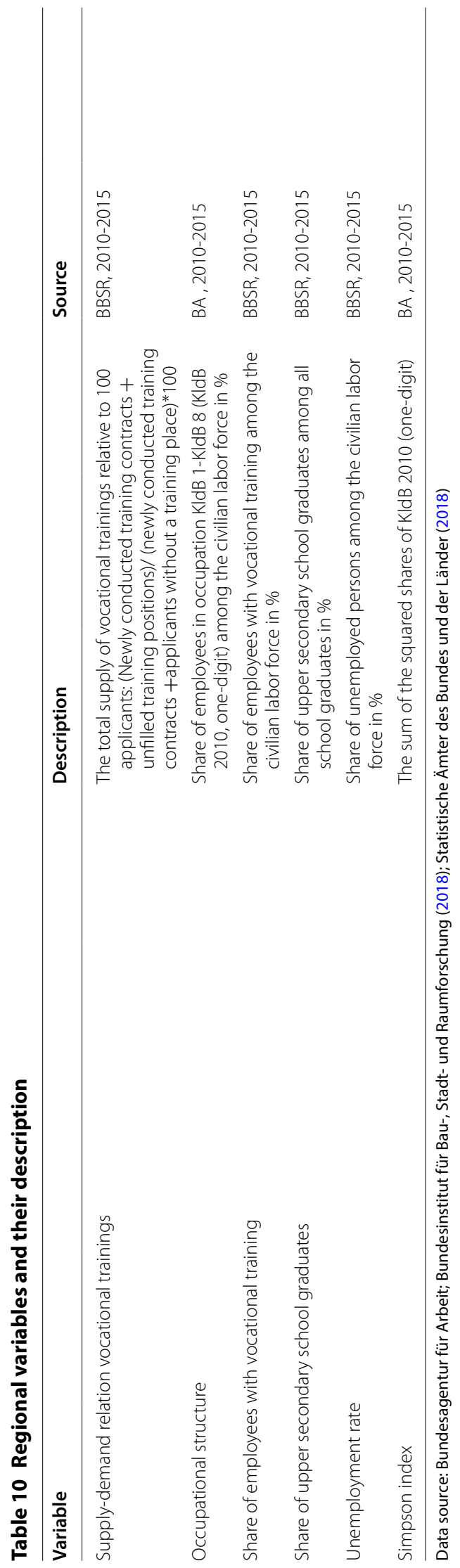


Table 11 Descriptive statistics of the regional variables

\begin{tabular}{|c|c|c|c|c|}
\hline & Mean & SD & Min & Max \\
\hline Share_Agriculture & 0.02 & 0.01 & 0.01 & 0.06 \\
\hline Share_Production & 0.24 & 0.06 & 0.13 & 0.40 \\
\hline Share_Construction & 0.07 & 0.01 & 0.04 & 0.10 \\
\hline Share_Science & 0.03 & 0.02 & 0.01 & 0.10 \\
\hline Share_Logistics & 0.13 & 0.02 & 0.09 & 0.18 \\
\hline Share_Trade & 0.12 & 0.01 & 0.09 & 0.17 \\
\hline Share_Clerical & 0.20 & 0.03 & 0.14 & 0.35 \\
\hline Share_Social services & 0.17 & 0.23 & 0.12 & 0.23 \\
\hline Supply-demand relation vocational trainings & 103.60 & 4.80 & 90.30 & 125.80 \\
\hline Share of upper secondary school graduates & 32.10 & 6.80 & 20.00 & 59.80 \\
\hline Unemployment rate & 6.70 & 2.90 & 2.10 & 14.80 \\
\hline Simpson index & 0.17 & 0.02 & 0.15 & 0.24 \\
\hline
\end{tabular}

Data source: Bundesagentur für Arbeit; Bundesinstitut für Bau-, Stadt- und Raumforschung (2018); Statistische Ämter des Bundes und der Länder 2018

by "low" and "rarely" and an upward deviation by "high" and "often". The heterogeneity within one occupational group is indicated by "low to average".

Indicator values for the different dimensions were derived from representative surveys which evaluate the working conditions of employees in Germany (DGB) and of the survey conducted of European working conditions (Eurofound), including 28 European countries, of employees and self-employed persons (Eurofound 2017; Institut DGBIndex Gute Arbeit 2012, 2015). The indicator physical demands includes the intensity and the frequency of physical demanding tasks in different occupations, differentiating from "low" to "high" physical demands (Eurofound 2017; Institut DGB-Index Gute Arbeit 2015; Sächsisches Staatsministerium für Wirtschaft, Arbeit und Verkehr 2018). Shift work and work on the weekends describe the frequency of atypical working hours in different occupational groups, ranging from "rarely" to "often" (Eurofound 2017; Institut DGB-Index Gute Arbeit 2012; Sächsisches Staatsministerium für Wirtschaft, Arbeit und Verkehr 2018).

The skill demand level of occupational groups has been derived from the share of LSS, ISS and USS graduates in vocational trainings in Germany (Statistik der Bundesagentur für Arbeit 2019c). A high share of LSS graduates and a low share of USS graduates indicate a low skill level of an occupational category. A low share of LSS graduates and a high share of USS graduates, on the contrary, indicate a high skill demand level. Finally, the income potential of the eight occupational groups is assessed by using German data on gross annual income of employees and trainees by occupations (KldB 2010) (Statistisches Bundesamt 2016). ${ }^{17}$

${ }^{17}$ The gross annual income does not include the income of the self-employed. 


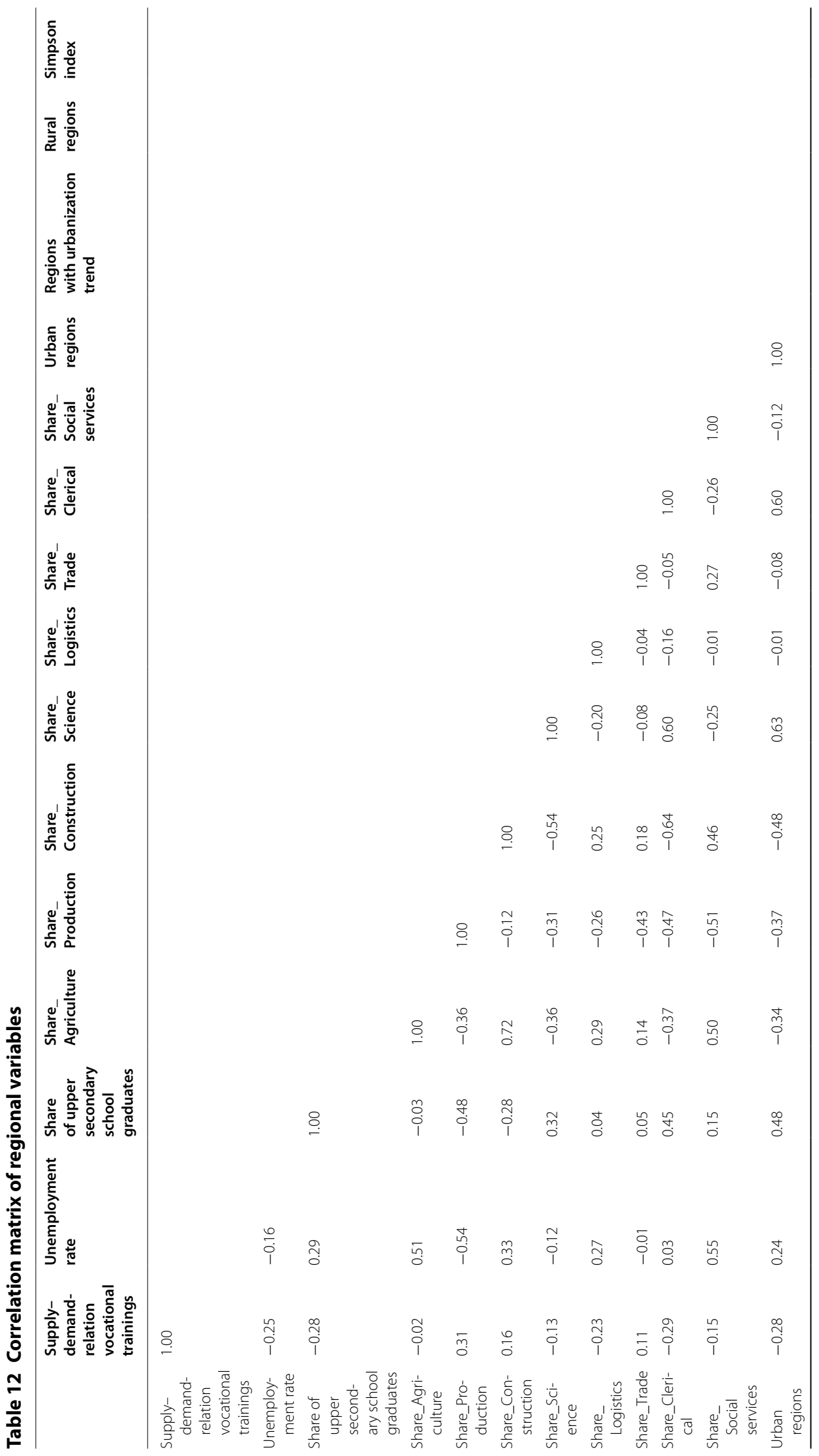




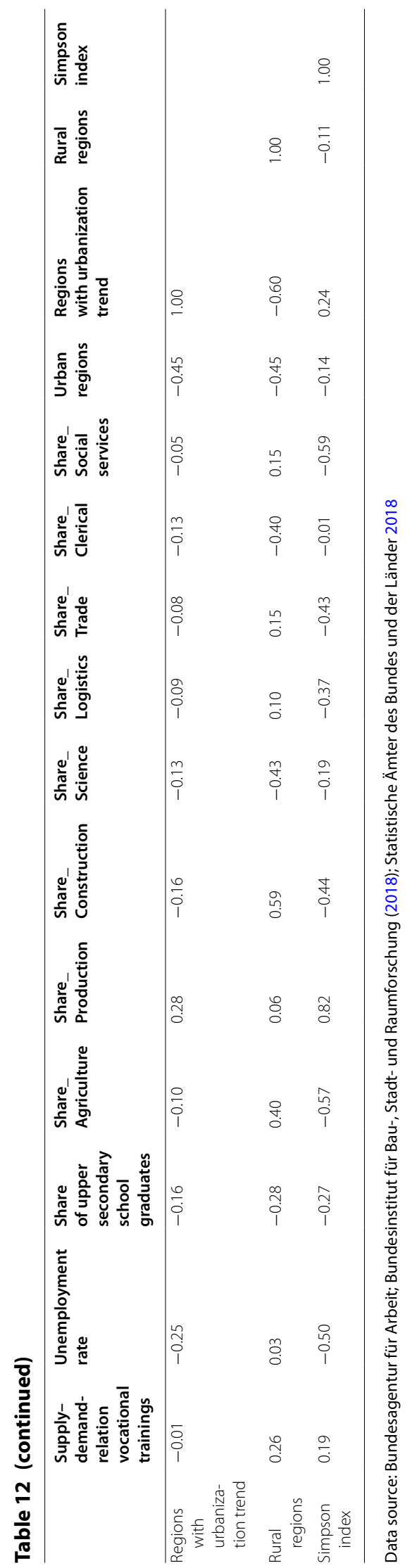


Received: 26 March 2020 Accepted: 27 November 2020

Published online: 02 February 2021

\section{References}

Di Addario S (2011) Job search in thick markets. J Urban Econ 69:303-318. https://doi.org/10.1016/j.jue.2011.01.001 Albert C (2000) Higher education demand in Spain: the influence of labour market signals and family background. High Educ 40:147-162

Arcidiacono P (2004) Ability sorting and the returns to college major. J Econ 121:343-375

Autorengruppe Bildungsberichterstattung (2018) Bildungsbericht 2018: Bildung in Deutschland 2018: Ein indikatorengestützter Bericht mit Analyse zu Wirkungen und Erträgen von Bildung, Bielefeld

Baethge M, Wolter A (2015) The German skill formation model in transition: from dual system of VET to higher education? J Labour Market Res 48:97-112. https://doi.org/10.1007/s12651-015-0181-x

Bleakley H, Lin J (2012) Thick-market effects and churning in the labor market: evidence from US cities. J Urban Econ 72:87-103

Blossfeld HP, Roßbach HG, Maurice J von (eds) (2011) Education as a Lifelong Process. The German National Educational Panel Study (NEPS): Zeitschrift für Erziehungswissenschaft: Sonderheft. Vol. 14,. VS Verlag für Sozialwissenschaften, Wiesbaden

Bol T, Ciocca Eller C, van de Werfhorst HG, DiPrete TA (2019) School-to-work linkages, educational mismatches, and labor market outcomes. Am Sociol Rev 84:275-307. https://doi.org/10.1177/0003122419836081

Bolder A (1975) Strukturelle und sozio-ökologische Determinanten des Ausbildungsweges: zu den Auswirkungen horizontaler und vertikaler Disparitäten im Bildungsbereich. Dissertation, Universität Köln

Bradley S, Taylor J (2004) The economics of secondary schooling. In: Johnes G, Johnes J (eds) International handbook on the economics of education. Edward Elgar, Cheltenham Northampton, pp 368-414

Bundesagentur für Arbeit (2011) Klassifizierung der Berufe 2010-Band1: Systematischer und alphabetischer Teil mit Erläuterungen. Bundesagentur für Arbeit, Nürnberg

Bundesagentur für Arbeit (2017) Blickpunkt Arbeitsmarkt: Der Ausbildungsmarkt im Jahr 2015/2016, Nürnberg

Bundesinstitut für Bau-, Stadt- und Raumforschung (2016) Laufende Raumbeobachtung - Raumabgrenzungen: StadtLand-Regionen - Siedlungsstrukturtyp. https://www.bbsr.bund.de/BBSR/DE/Raumbeobachtung/Raumabgrenzunge n/deutschland/regionen/StadtLandRegionen_Typen/SLR_node.html. Accessed 15 January 2020

Bundesinstitut für Bau-, Stadt- und Raumforschung (2017) Laufende Raumbeobachtung - Raumabgrenzungen: Raumordnungsregionen. https://www.bbsr.bund.de/BBSR/DE/Raumbeobachtung/Raumabgrenzungen/Raumordnungsreg ionen/raumordnungsregionen_node.html. Accessed 2 April 2019

Bundesinstitut für Bau-, Stadt- und Raumforschung (2018) INKAR-Indikatoren und Karten zur Raum- und Stadtentwicklung. www.bbsr.bund.de. Accessed 2 April 2019

Bundesinstitut für Bau-, Stadt- und Raumforschung (2019) NKAR-Schulabgänger mit Hochschulreife. www.bbsr.bund.de. Accessed 2 April 2019

Bundesinstitut für Berufsbildung (2019) Verzeichnis der anerkannten Ausbildungsberufe 2019: Bekanntmachung des Verzeichnisses der anerkannten Ausbildungsberufe und des Verzeichnisses der zuständigen Stellen, Bonn

Bundesinstitut für Berufsbildung (2020) Datenreport zum Berufsbildungsbericht 2020: Informationen und Analysen zur Entwicklung der beruflichen Bildung, Bonn

Cameron AC, Trivedi PK (2009) Microeconometrics using stata. Stata Press, College Station, TX

Daniel H-D, Hannover B, Köller O, Lenzen D, McElvany N, Roßbach H-G, Seidel T, Tippelt R, Wößmann L (2019) Region und Bildung: Mythos Stadt-Land, Münster

Ditton H (1992) Ungleichheit und Mobilität durch Bildung: Theorie und empirische Untersuchung über sozialräumliche Aspekte von Bildungsentscheidungen. Juventa-Verlag, Weinheim und München

Drost A (2002) The dynamics of occupational choice: theory and evidence. Labour 16:201-233

Dummert S, Leber U, Schwengler B (2019) Unfilled training positions in Germany —regional and establishment-specific determinants. Jahrbücher für Nationalökonomie und Statistik 239:661-701. https://doi.org/10.1515/jbnst-2018-0014

Eberhard V (2012) Der Übergang von der Schule in die Berufsausbildung: Ein ressourcentheoretisches Modell der Übergangschancen von Ausbildungsstellenbewerbern. Bertelsmann Verlag, Bielefeld

Ehrenberg RG, Smith RS (2017) Modern Labor Economics. Routledge, Thirteenth Edition. | New York: Routledge, 2017. | Revised edition of the authors' Modern labor economics, [2015]

Eurofound (2017) Sixth European Working Conditions Survey: Overview report (2017 update). EF, Luxembourg. Accessed 1 March 2019

Falch T, Lujala P, Strøm B (2013) Geographical constraints and educational attainment. Regional Sci Urban Econ 43:164-176

Fouarge D, Kriechel B, Dohmen T (2014) Occupational sorting of school graduates: the role of economic preferences. J Econ Behav Organ 106:335-351

Frenette M (2004) Access to college and university: Does distance to school matter? Canadian Public Policy/Analyse de Politiques 15:427-443

Frenette M (2006) Too far to go on? Distance to School and University Participation. Education Econ 14:31-58. https://doi. org/10.1080/09645290500481865

Ghignoni E, Verashchagina A (2014) Educational qualifications mismatch in Europe. Is it demand or supply driven? J Comparative Econ 42:670-692

Gibbons S, Vignoles A (2012) Geography, choice and participation in higher education in England. Regional Sci Urban Econ 42:98-113

Glauser D, Becker R (2016) VET or general education? Effects of regional opportunity structures on educational attainment in German-speaking Switzerland. Empirical Res Vocational Education Training 8:8 
Graf L (2015) Germany: Stability and Change. In: Corner T (ed) Education in the European Union: Pre-2003 Member States. Bloomsbury, New York, pp 125-154

Green AE, White R (2008) Shaped by place: young people's decisions about education, training and work. Benefits $16: 213-224$

Hagenaars AJM, Vos K de, Asghar Zaidi M (1994) Poverty statistics in the late 1980s: Research based on micro-data, Luxembourg

Halpern JJ, Stern RC (1998) Beneath the social science debate: economic and social notion of rationality. In: Stern RC (ed) Halpern JJ. Nonrational aspects of organizational decision making. Cornell University Press, Debating rationality, pp $1-17$

Heisig JP, Solga H (2015) Secondary education systems and the general skills of less- and intermediate-educated adults. Sociol Educ 88:202-225. https://doi.org/10.1177/0038040715588603

Hillmert S, Hartung A, Weßling K (2017) A decomposition of local labour-market conditions and their relevance for inequalities in transitions to vocational training. Eur Sociol Rev 33:534-550. https://doi.org/10.1093/esr/jcx057

Institut DGB-Index Gute Arbeit (2012) Stressfaktor-Wochenend-Arbeit: so beurteilen die Beschäftigten die Lage, Berlin. https://index-gute-arbeit.dgb.de/veroeffentlichungen/sonderauswertungen. Accessed 10 February 2019

Institut DGB-Index Gute Arbeit (2015) Arbeitsbedingte Belastung und Beanspruchung: Wie die Beschäftigten den Zusammenhang beurteilen, Berlin. https://index-gute-arbeit.dgb.de/++co++482296a0-6698-11 e5-baa6-52540 023ef1a. Accessed 10 February 2019

Karlsson C, Pettersson L (2005) Regional productivity and accessibility to knowledge and dense markets. CESIS WP 32

Kirkeboen LJ, Leuven E, Mogstad M (2016) Field of study, earnings, and self-selection*. Q J Econ 131:1057-1111. https:// doi.org/10.1093/qje/qjw019

Kleinert C, Vosseler A, Blien U (2018) Classifying vocational training markets. Ann Reg Sci 61:31-48

Knoll B, Riedel N, Schlenker E (2017) He's a chip off the old block - the persistence of occupational choices across generations. Labour 31:174-203. https://doi.org/10.1111/labr.12091

Lehmann EE, Schenkenhofer J, Wirsching K (2019) Hidden champions and unicorns: a question of the context of human capital investment. Small Bus Econ 52:359-374. https://doi.org/10.1007/s11187-018-0096-3

Levels M, van der Velden R, Allen J (2014) Educational mismatches and skills: new empirical tests of old hypotheses. Oxford Economic Papers 66:959-982. https://doi.org/10.1093/oep/gpu024

Lüdemann E, Schwerdt G (2013) Migration background and educational tracking. J Population Econ 26:455-481

Ludwig-Mayerhofer W, Solga H, Leuze K, Dombrowski R, Künster R, Ebralidze E, Fehring G, Kühn S (2011) 16 Vocational education and training and transitions into the labor market. Zeitschrift für Erziehungswissenschaft 14:251-266. https://doi.org/10.1007/s11618-011-0189-0

Margarian A (2018) Strukturwandel in der Wissensökonomie: Eine Analyse von Branchen-, Lage- und Regionseffekten in Deutschland. Thünen Report, vol 60. Johann Heinrich von Thünen-Institut, Braunschweig, Germany

Mocetti S (2012) Educational choices and the selection process: before and after compulsory schooling. Education Economics 20:189-209

Montmarquette C, Cannings K, Mahseredjian S (2002) How do young people choose college majors? Econ Education Rev 21:543-556

Muehlemann S, Wolter SC (2011) Firm-sponsored training and poaching externalities in regional labor markets. Regional Sci Urban Econ 41:560-570. https://doi.org/10.1016/j.regsciurbeco.2011.04.003

Nguyen AN, Taylor J (2003) Post-high school choices: new evidence from a multinomial logit model. J Population Econ 16:287-306

Nordin M, Persson I, Rooth D-O (2010) Education-occupation mismatch: Is there an income penalty? Econ Education Rev 29:1047-1059

OECD (2015) In it together: why less inequality benefits all. OECD Publishing, Paris

OECD (2020) What are equivalence scales? http://www.oecd.org/els/soc/OECD-Note-EquivalenceScales.pdf

Pätzold G (2008) Übergang Schule—Berufsausbildung. In: Helsper W, Böhme J (eds) Handbuch der Schulforschung, 2nd edn. Springer, Wiesbaden, pp 593-610

Pohl S, Carstensen CH (2012) NEPS technical report-Scaling the data of the competence tests

Pothier D (2018) Occupational segregation and the (Mis)allocation of talent. Scand J Econ 120:242-267. https://doi. org/10.1111/sjoe.12206

Protsch P, Dieckhoff M (2011) What matters in the transition from school to vocational training in Germany. Eur Soc 13:69-91. https://doi.org/10.1080/14616696.2010.540352

Protsch P, Solga H (2016) The social stratification of the German VET system. J Education Work 29:637-661. https://doi. org/10.1080/13639080.2015.1024643

Raffe D, Willms JD (1989) Schooling the discouraged worker: local-labour-market effects on educational participation. Sociology 23:559-581

Reimer D, Pollak R (2010) Educational expansion and its consequences for vertical and horizontal inequalities in access to higher education in West Germany. Eur Sociol Rev 26:415-430. https://doi.org/10.1093/esr/jcp029

Sá C, Florax RJGM, Rietveld P (2006) Does Accessibility to higher education matter? Choice behaviour of high school graduates in the Netherlands. Spatial Econ Anal 1:155-174. https://doi.org/10.1080/17421770601009791

Sächsisches Staatsministerium für Wirtschaft, Arbeit und Verkehr (2018) Qualität der Arbeitsbedingungen von Beschäftigten in Sachsen 2017: Ergebnisse der Repräsentativbefragung zum DGB-Index Gute Arbeit in Sachsen, Dresden. http://www.arbeit.sachsen.de/download/DGB-Index-Sachsen-2017-Langfassung.pdf. Accessed 15 February 2019

Seeber S, Michaelis C (2015) Zur Entwicklung des Schulberufssystems: Eine Analyse im Kontext demografischer Veränderungen und arbeitsmarktbezogener Herausforderungen. Recht der Jugend und des Bildungswesens 63:271-290. https://doi.org/10.5771/0034-1312-2015-3-271

Sewell WH, Orenstein AM (1965) Community of residence and occupational choice. Am J Sociol 70:551-563

Simon CJ (1988) Frictional unemployment and the role of industrial diversity. Q J Econ 103:715. https://doi. org/10.2307/1886071 
Sixt M (2010) Regionale Strukturen als herkunftsspezifische Determinanten von Bildungsentscheidungen. Dissertation, Universität Kassel

Somers MA, Cabus SJ, Groot W, van den Brink HM (2019) Horizontal mismatch between employment and field of education: evidence from a systematic literature review. J Econ Surveys 33:567-603. https://doi.org/10.1111/joes.12271

Spiess CK, Wrohlich K (2010) Does distance determine who attends a university in Germany? Econ Education Rev 29:470-479

Statistik der Bundesagentur für Arbeit (2015) German Classification of Occupations 2010, Nürnberg

Statistik der Bundesagentur für Arbeit (2019a) Berichte: Arbeitsmarkt kompakt: Situation am Ausbildungsmarkt, Nürnberg

Statistik der Bundesagentur für Arbeit (2019b) Seit Beginn des Berichtsjahres gemeldete Berufsausbildungsstellen und Bewerber für Berufsausbildungsstellen nach diversen Berufsaggregaten, Nürnberg

Statistik der Bundesagentur für Arbeit (2019c) Sozialversicherungspflichtig Beschäftigte nach Geschlecht, ausgeübter Tätigkeit KIdB 2010 und Schulabschluss, Nürnberg

Statistische Ämter des Bundes und der Länder (2018) Regionaldatenbank Deutschland. www.regionalstatistik.de. Accessed 2 April 2019

Statistisches Bundesamt (2016) Verdienststrukturerhebung: Niveau, Verteilung und Zusammensetzung der Verdienste und der Arbeitszeiten abhängiger Beschäftigungsverhältnisse - Ergebnisse für Deutschland 2014. Fachserie 16, Wiesbaden

Statistisches Bundesamt (2019a) Bevölkerung und Erwerbstätigkeit: Bevölkerung mit Migrationshintergrund - Ergebnisse des Mikrozensus 2018. Fachserie 1, Wiesbaden. https://www.destatis.de/DE/Themen/Gesellschaft-Umwelt/ Bevoelkerung/Migration-Integration/Publikationen/Downloads-Migration/migrationshintergrund-2010220187004. pdf?_blob=publicationFile. Accessed 4 February 2020

Statistisches Bundesamt (2019b) Bildung und Kultur: Berufliche Bildung 2018. Fachserie 11 Reihe 3

Steinhauer HW, Zinn S (2016) NEPS Technical Report for Weighting: Weighting the sample of Starting Cohort 4 of the National Educational Panel Study (Waves 1 to 6). NEPS Survey Paper, Bamberg. https://www.neps-data.de/Portals/0/ Survey\%20Papers/SP_Il.pdf. Accessed 30 June 2020

Stüber H (2016) Berufsspezifische Lebensentgelte: Qualifikation zahlt sich aus. IAB-Kurzbericht

Tumino A (2013) The effect of local labour market conditions on educational choices: a cross country comparison. ImPRovE Discussion Paper 13/06, Antwerp

Volodina A, Nagy G (2016) Vocational choices in adolescence: the role of gender, school achievement, self-concepts, and vocational interests. J Vocat Behav 95:58-73

Weishaupt H (2018) Bildung und Region. In: Tippelt R, Schmidt-Hertha B (eds) Handbuch Bildungsforschung, 4., durchges. Aufl. 2018. Springer Fachmedien Wiesbaden, Wiesbaden, pp. 271-286

Weßling K, Hartung A, Hillmert S (2015) Spatial structure counts: the relevance of regional labour-market conditions for educational transitions to vocational training. Empirical Res Vocational Education Training 7:12. https://doi. org/10.1186/s40461-015-0024-6

Wicht A, Ludwig-Mayerhofer W (2014) The impact of neighborhoods and schools on young people's occupational aspirations. J Vocat Behav 85:298-308

Wiswall M, Zafar B (2015) Determinants of college major choice: identification using an information experiment. Rev Econ Studies 82:791-824

Wochnik M (2014) Jugendliche im ländlichen Raum-Heimatbezug und Berufswahl. Die berufsbildende Schule 66:215-218

\section{Publisher's Note}

Springer Nature remains neutral with regard to jurisdictional claims in published maps and institutional affiliations.

\section{Submit your manuscript to a SpringerOpen ${ }^{\circ}$ journal and benefit from:}

- Convenient online submission

- Rigorous peer review

- Open access: articles freely available online

- High visibility within the field

- Retaining the copyright to your article

Submit your next manuscript at $\boldsymbol{\Delta}$ springeropen.com 